\title{
LEVEL II SCOUR ANALYSIS FOR BRIDGE 46 (LINCTH00060046) on TOWN HIGHWAY 6, crossing the NEW HAVEN RIVER, LINCOLN, VERMONT
}

Open-File Report 98-023

Prepared in cooperation with

VERMONT AGENCY OF TRANSPORTATION

and

FEDERAL HIGHWAY ADMINISTRATION

U.S. Department of the Interior U.S. Geological Survey

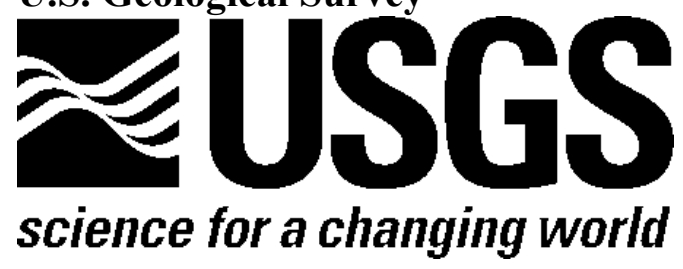




\section{LEVEL II SCOUR ANALYSIS FOR BRIDGE 46 (LINCTH00060046) on TOWN HIGHWAY 6, crossing the NEW HAVEN RIVER, \\ LINCOLN, VERMONT \\ By EMILY C. WILD}

U.S. Geological Survey Open-File Report 98-023

Prepared in cooperation with

VERMONT AGENCY OF TRANSPORTATION

and

FEDERAL HIGHWAY ADMINISTRATION 


\title{
U.S. DEPARTMENT OF THE INTERIOR BRUCE BABBITT, Secretary
}

\author{
U.S. GEOLOGICAL SURVEY
}

Thomas Casadevall, Acting Director

For additional information write to:

District Chief

U.S. Geological Survey 361 Commerce Way

Pembroke, NH 03275-3718
Copies of this report may be purchased from:

U.S. Geological Survey

Branch of Information Services

Open-File Reports Unit

Box 25286

Denver, CO 80225-0286 


\section{CONTENTS}

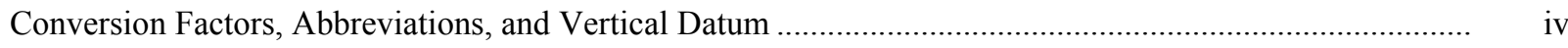

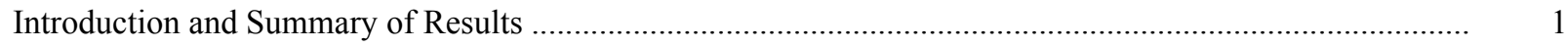

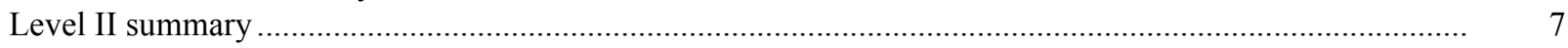

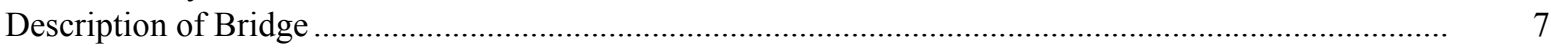

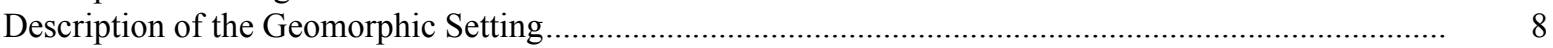

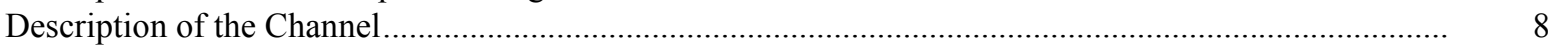

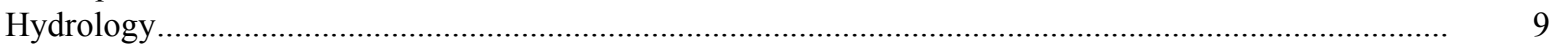

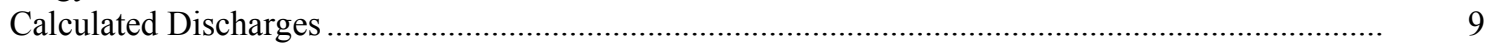

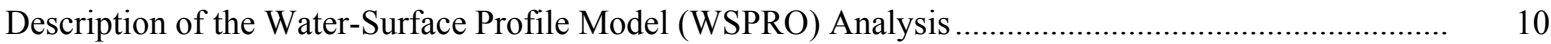

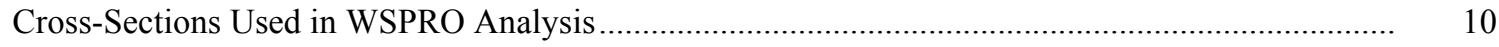

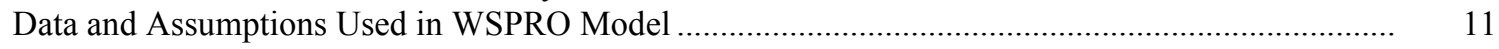

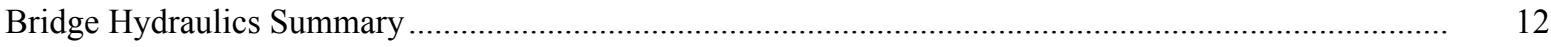

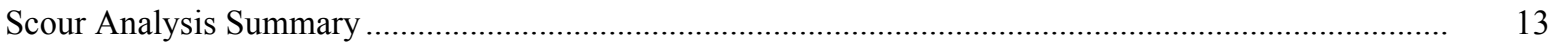

Special Conditions or Assumptions Made in Scour Analysis ................................................... 13

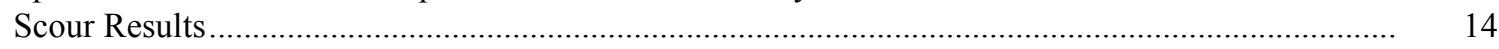

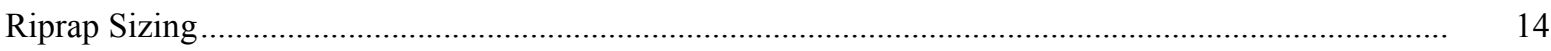

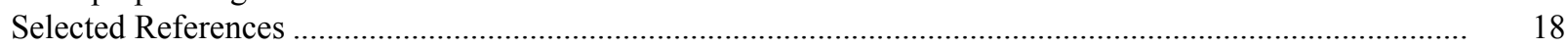

Appendices:

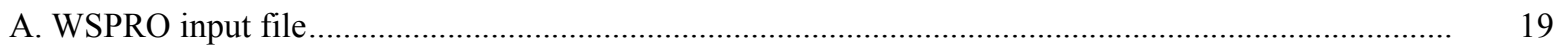

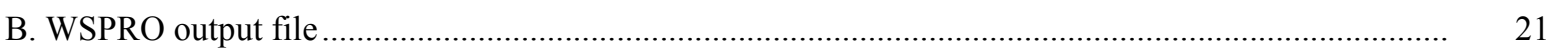

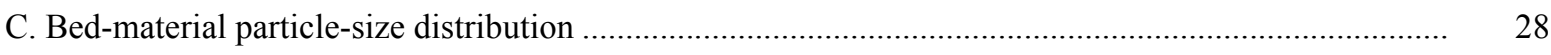

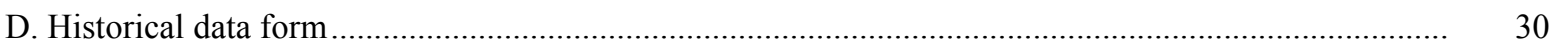

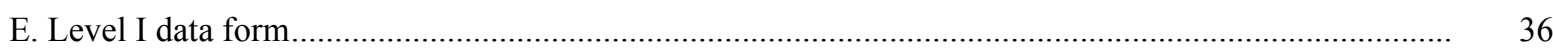

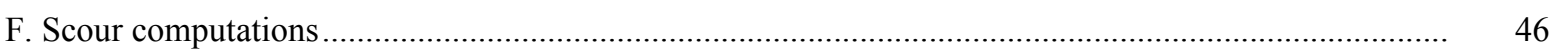

\section{FIGURES}

1. Map showing location of study area on USGS $1: 24,000$ scale map ................................................ 3

2. Map showing location of study area on Vermont Agency of Transportation town

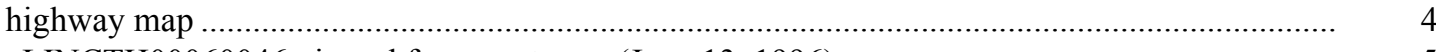

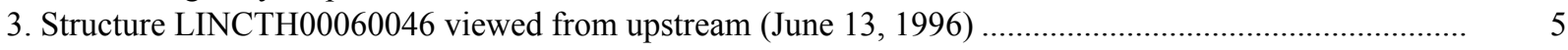

4. Downstream channel viewed from structure LINCTH00060046 (June 13, 1996)................................. 5

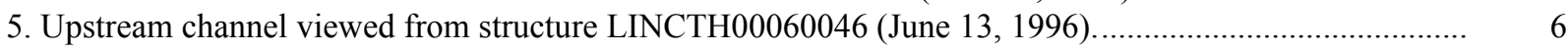

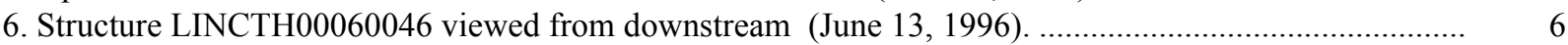

7. Water-surface profiles for the 100- and 500-year discharges at structure

LINCTH00060046 on Town Highway 6, crossing the New Haven River,

Lincoln, Vermont.

8. Scour elevations for the 100- and 500-year discharges at structure

LINCTH00060046 on Town Highway 6, crossing the New Haven River,

Lincoln, Vermont.

\section{TABLES}

1. Remaining footing/pile depth at abutments for the 100-year discharge at structure

LINCTH00060046 on Town Highway 6, crossing the New Haven River,

Lincoln, Vermont

2. Remaining footing/pile depth at abutments for the 500-year discharge at structure

LINCTH00060046 on Town Highway 6, crossing the New Haven River,

Lincoln, Vermont 


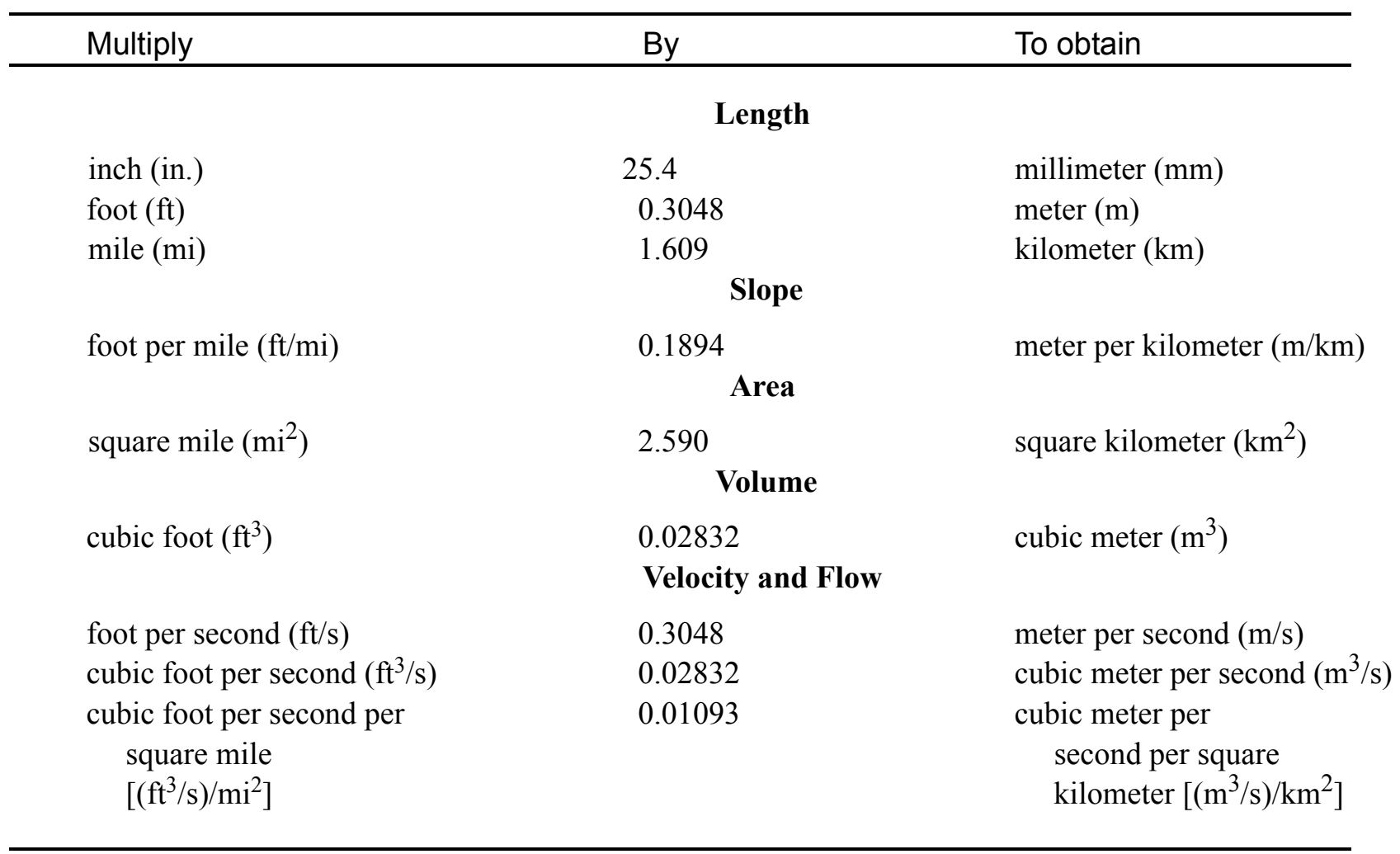

\section{OTHER ABBREVIATIONS}

$\begin{array}{lrlr}\text { BF } & \begin{array}{r}\text { bank full } \\ \text { cfs }\end{array} & \text { LWW } & \text { cubic feet per second } \\ \mathrm{D}_{50} & \text { Max } & \begin{array}{r}\text { left wingwall } \\ \text { maximum } \\ \mathrm{DS}\end{array} \\ \mathrm{elev} & \text { median diameter of bed material } & \text { MC } & \text { main channel } \\ \mathrm{d} / \mathrm{p} & \text { elevation } & \text { RABUT } & \text { right abutment } \\ \mathrm{ft}^{2} & \text { flood plain } & \text { RB } & \text { face of right abutment } \\ \mathrm{ft} / \mathrm{ft} & \text { square feet } & \text { ROB } & \text { right bank } \\ \text { FEMA } & \text { feet per foot } & \text { RWW } & \text { right overbank } \\ \text { FHWA } & \text { Federal Emergency Management Agency } & \text { TH } & \text { right wingwall } \\ \text { JCT } & \text { Federal Highway Administration } & \text { UB } & \text { under bridge } \\ \text { LAB } & \text { junction } & \text { US } & \text { upstream } \\ \text { LABUT } & \text { left abutment } & \text { USGS } & \text { United States Geological Survey } \\ \text { LB } & \text { face of left abutment } & \text { VTAOT } & \text { Vermont Agency of Transportation } \\ \text { LOB } & \text { left bank } & \text { WSPRO } & \text { water-surface profile model } \\ & \text { left overbank } & \text { yr } & \text { year }\end{array}$

In this report, the words "right" and "left" refer to directions that would be reported by an observer facing downstream.

Sea level: In this report, "sea level" refers to the National Geodetic Vertical Datum of 1929-- a geodetic datum derived from a general adjustment of the first-order level nets of the United States and Canada, formerly called Sea Level Datum of 1929.

In the appendices, the above abbreviations may be combined. For example, USLB would represent upstream left bank. 


\title{
LEVEL II SCOUR ANALYSIS FOR BRIDGE 46 (LINCTH00060046) ON TOWN HIGHWAY 6, CROSSING THE NEW HAVEN RIVER, LINCOLN, VERMONT
}

\author{
By Emily C. Wild
}

\section{INTRODUCTION AND SUMMARY OF RESULTS}

This report provides the results of a detailed Level II analysis of scour potential at structure LINCTH00060046 on Town Highway 6 crossing the New Haven River, Lincoln, Vermont (figures 1-8). A Level II study is a basic engineering analysis of the site, including a quantitative analysis of stream stability and scour (FHWA, 1993). Results of a Level I scour investigation also are included in appendix $\mathrm{E}$ of this report. A Level I investigation provides a qualitative geomorphic characterization of the study site. Information on the bridge, gleaned from Vermont Agency of Transportation (VTAOT) files, was compiled prior to conducting Level I and Level II analyses and is found in appendix D.

The site is in the Green Mountain section of the New England physiographic province in west-central Vermont. The $45.9-\mathrm{mi}^{2}$ drainage area is in a predominantly suburban and forested basin. In the vicinity of the study site, the surface cover is forest upstream of the bridge. The downstream right overbank near the bridge is suburban with buildings, homes, lawns, and pavement (less than fifty percent). The downstream left overbank is brushland while the immediate banks have dense woody vegetation.

In the study area, the New Haven River has an incised, sinuous channel with a slope of approximately $0.01 \mathrm{ft} / \mathrm{ft}$, an average channel top width of $95 \mathrm{ft}$ and an average bank height of $7 \mathrm{ft}$. The channel bed material ranges from sand to bedrock with a median grain size $\left(\mathrm{D}_{50}\right)$ of $120.7 \mathrm{~mm}(0.396 \mathrm{ft})$. The geomorphic assessment at the time of the Level I and Level II site visit on June 13, 1996, indicated that the reach was stable.

The Town Highway 34 crossing of the New Haven River is a 85-ft-long, two-lane bridge consisting of an 80-foot steel arch truss (Vermont Agency of Transportation, written communication, December 14, 1995). The opening length of the structure parallel to the bridge face is 69 feet. The bridge is supported by vertical, concrete abutments with wingwalls. The channel is skewed approximately 25 degrees to the opening while the opening-skew-to-roadway is 5 degrees. 
A scour hole $2.0 \mathrm{ft}$ deeper than the mean thalweg depth was observed in the downstream channel during the Level I assessment. Protection measures at the site include type- 1 stone fill (less than 12 inches diameter) at the upstream left wingwall, type-2 stone fill (less than 36 inches diameter) at the downstream end of the downstream left wingwall, and type- 3 stone fill (less than 48 inches diameter) at the upstream right wingwall and the downstream end of the downstream right wingwall. Additional details describing conditions at the site are included in the Level II Summary and appendices D and E.

Scour depths and recommended rock rip-rap sizes were computed using the general guidelines described in Hydraulic Engineering Circular 18 (Richardson and Davis, 1995). Total scour at a highway crossing is comprised of three components: 1) long-term streambed degradation; 2) contraction scour (due to accelerated flow caused by a reduction in flow area at a bridge) and; 3 ) local scour (caused by accelerated flow around piers and abutments). Total scour is the sum of the three components. Equations are available to compute depths for contraction and local scour and a summary of the results of these computations follows.

Contraction scour for all modelled flows ranged from 0.0 to $1.7 \mathrm{ft}$. The worst-case contraction scour occurred at the incipient roadway-overtopping discharge. Left abutment scour ranged from 12.9 to $17.8 \mathrm{ft}$. Right abutment scour ranged from 5.9 to $11.9 \mathrm{ft}$. The worst-case abutment scour occurred at the incipient roadway-overtopping discharge. Additional information on scour depths and depths to armoring are included in the section titled "Scour Results". Scoured-streambed elevations, based on the calculated scour depths, are presented in tables 1 and 2. A cross-section of the scour computed at the bridge is presented in figure 8. Scour depths were calculated assuming an infinite depth of erosive material and a homogeneous particle-size distribution.

It is generally accepted that the Froehlich equation (abutment scour) gives "excessively conservative estimates of scour depths" (Richardson and Davis, 1995, p. 47). Usually, computed scour depths are evaluated in combination with other information including (but not limited to) historical performance during flood events, the geomorphic stability assessment, existing scour protection measures, and the results of the hydraulic analyses. Therefore, scour depths adopted by VTAOT may differ from the computed values documented herein. 


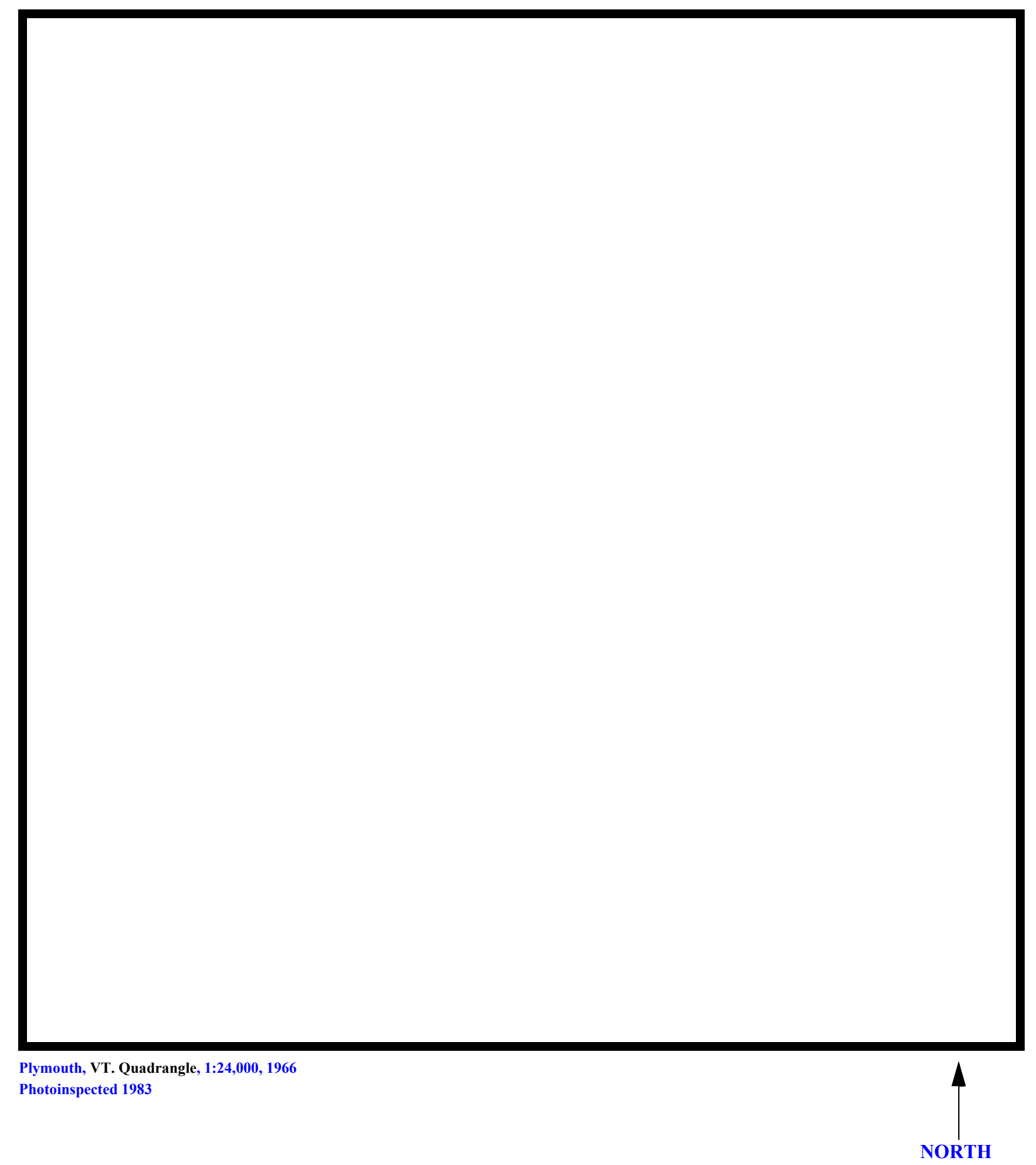

Figure 1. Location of study area on USGS 1:24,000 scale map. 
Figure 2. Location of study area on Vermont Agency of Transportation town highway map. 

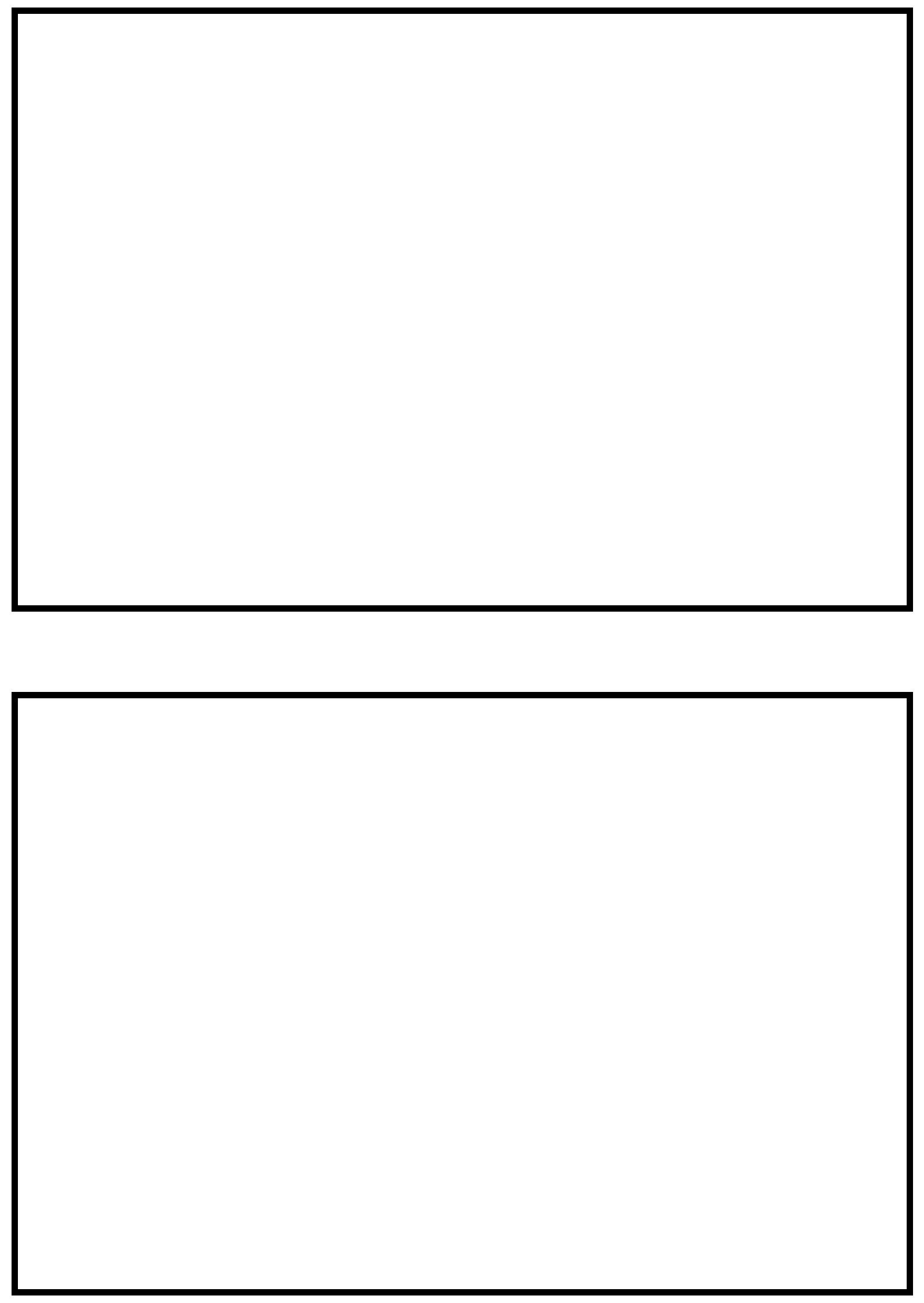



\section{LEVEL II SUMMARY}

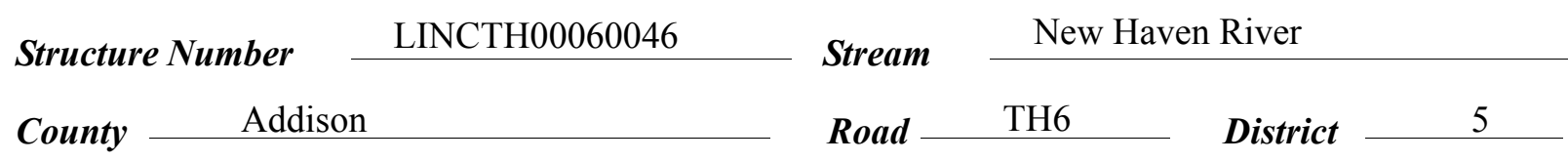

\section{Description of Bridge}

Bridge length $\frac{85}{} \boldsymbol{f t} \quad$ Bridge width $\frac{21.2}{f t} \quad$ Max span length $\frac{80}{f t}$ Alignment of bridge to road (on curve or straight) Vertical, concrete Abutment type

Stone fill on abutment? No Embankment type Straight nasmintinu af atans fill Type- 1 at the upstream left wingwall, type- 2 at the downstream
. Sloping $06 / 13 / 96$ end of the downstream left wingwall, and type-3 at the upstream right wingwall and the downstream end of the downstream right wingwall.

Abutments and wingwalls are concrete. There is a one to two foot deep scour hole in front of the right abutment.

Is bridge skewed to flood flow according to $\mathrm{N}^{\text {r survey? }} \quad \frac{\mathrm{Y}}{\text { Angle }}$

Debris accumulation on bridge at time of Level I or Level II site visit:

\begin{tabular}{|c|c|c|c|}
\hline & $\begin{array}{c}\text { Date of insnortion } \\
06 / 13 / 96\end{array}$ & $\begin{array}{l}\text { Percent of oldmmal } \\
\text { blocked hortzontatly }\end{array}$ & $\begin{array}{l}\text { Percent of } 0 \\
\text { blocked verticatty }\end{array}$ \\
\hline vol & 06/13/96 & 0 & 0 \\
\hline
\end{tabular}

Level II

Moderate. Some debris has accumulated on upstream point bar, in front of upstream left wingwall and on downstream channel bar.

Potential for debris

Under bridge channel is narrower at the incipient roadway-overtopping discharge than the 100Doscriho anv foaturos noar ar at tho hridoo that mav affort flow, (includo ahsorvation datol year and 500-year discharges. During the site visit on June 13,1996, it was noted the left bridge seat is set back approximately 12 feet from the vertical left abutment. 


\section{Description of the Geomorphic Setting}

General topography The channel is located within a 100 foot-wide, narrow valley with steep valley walls on both sides.

Geomorphic conditions at bridge site: downstream (DS), upstream (US)

Date of inspection $\quad 06 / 13 / 96$

DS left: $\quad$ Moderately sloped overbank

DS right: $\quad$ Steep valley wall

US left: $\quad$ Moderately sloped overbank

US right: $\quad$ Steep valley wall

\section{Description of the Channel}

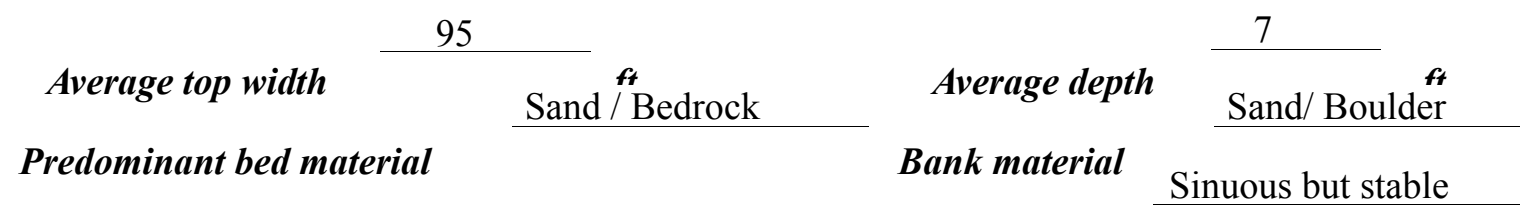

with alluvial channel boundaries and local anabranching downstream.

Vegetative co 1 Trees and brush

DS left: $\quad$ None. (Town Highway 1)

DS right: $\quad$ Trees and brush

US left: $\quad$ None. (Town Highway 1)

US right: $\quad \underline{\mathrm{Y}}$

Do banks appear stable? -

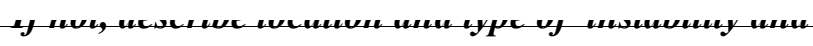
date of observatton. 


\section{Hydrology}

Drainage area $\stackrel{45.9}{\boldsymbol{m i}^{2}}$

Percentage of drainage area in physiographic provinces: (approximate)

Physiographic province/section

New England/ Green Mountain
Percent of drainage area 100

Is drainage area considered rural or urban? Rural Describe any significant

urbanization: There are a couple houses on the upstream left overbank area.

Is there a USGS gage on the stream of interest?

No

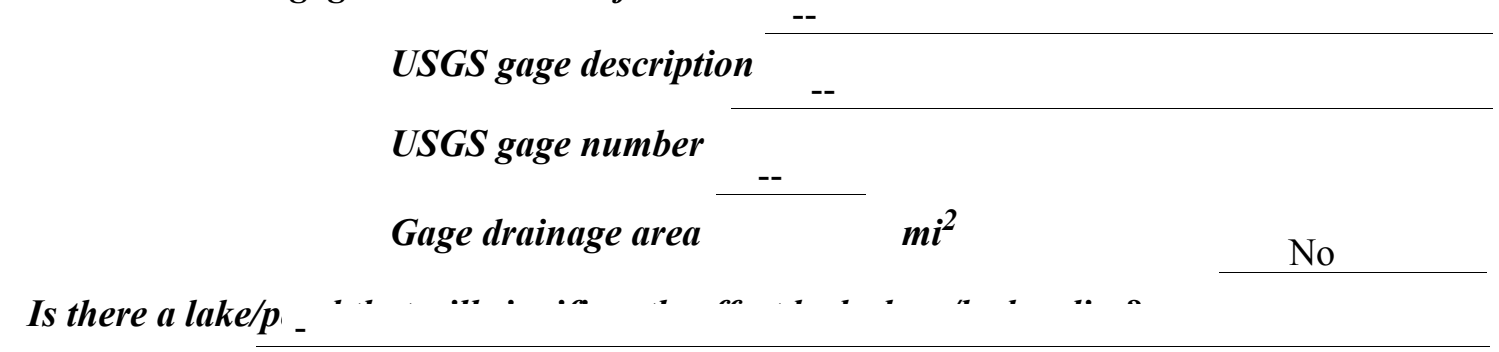

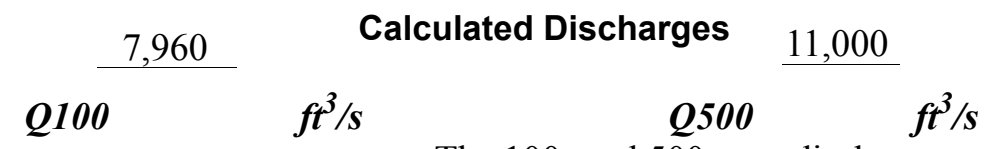

The 100- and 500-year discharges are based on a

drainage area relationship [(45,87/48.87)exp 0.67] with bridge number 11 in Bristol. Bridge

number 11 crosses the New Haven River downstream of this site and has flood frequency

estimates available from the VTAOT database. The drainage area above bridge number 11 is

48.87 square miles. These values are within a range defined by several empirical flood frequency curves (Benson, 1962; Johnson and Tasker, 1974; FHWA, 1983; Potter, 1957a\&b;

Talbot, 1887). 


\section{Description of the Water-Surface Profile Model (WSPRO) Analysis}

Datum for WSPRO analysis (USGS survey, sea level, VTAOT plans)

USGS survey

Datum tie between USGS survey and VTAOT plans

None

Description of reference marks used to determine USGS datum. $\quad$ RM1 is a chiseled X on top of the downstream left corner of the bridge (elev. $499.37 \mathrm{ft}$, arbitrary survey datum). RM2 is a chiseled X on top of the upstream right corner of the bridge (elev. $497.67 \mathrm{ft}$, arbitrary survey datum).

\section{Cross-Sections Used in WSPRO Analysis}

\begin{tabular}{cccl}
\hline${ }^{1}$ Cross-section & $\begin{array}{c}\text { Section } \\
\text { Reference } \\
\text { Distance } \\
\text { (SRD) } \text { in feet }\end{array}$ & $\begin{array}{c}{ }^{2} \text { Cross-section } \\
\text { development }\end{array}$ & \multicolumn{1}{c}{ Comments } \\
\hline EXIT1 & -75 & 1 & $\begin{array}{l}\text { Exit section } \\
\text { Downstream Full-valley } \\
\text { section (Templated from } \\
\text { EXITX) }\end{array}$ \\
BRIDG & 0 & 2 & $\begin{array}{l}\text { Bridge section } \\
\text { Road Grade section }\end{array}$ \\
RDWAY & 0 & 1 & $\begin{array}{l}\text { Modelled Approach sec- } \\
\text { tion (Templated from } \\
\text { APPR1 }\end{array}$ \\
& 12 & 1 & $\begin{array}{l}\text { APTEM) } \\
\text { Approach section as sur- } \\
\text { veyed (Used as a tem- } \\
\text { plate) }\end{array}$ \\
\hline
\end{tabular}

${ }^{1}$ For location of cross-sections see plan-view sketch included with Level I field form, Appendix E. For more detail on how cross-sections were developed see WSPRO input file. 


\section{Data and Assumptions Used in WSPRO Model}

Hydraulic analyses of the reach were done by use of the Federal Highway Administration's WSPRO step-backwater computer program (Shearman and others, 1986, and Shearman, 1990). The analyses reported herein reflect conditions existing at the site at the time of the study. Furthermore, in the development of the model it was necessary to assume no accumulation of debris or ice at the site. Results of the hydraulic model are presented in the Bridge Hydraulic Summary, appendix B, and figure 7.

Channel roughness factors (Manning's " $n$ ") used in the hydraulic model were estimated using field inspections at each cross section following the general guidelines described by Arcement and Schneider (1989). Final adjustments to the values were made during the modelling of the reach. Channel " $\mathrm{n}$ " values for the reach ranged from 0.055 to 0.060 , and overbank " $n$ " values ranged from 0.065 to 0.080 .

Normal depth at the exit section (EXIT1) was assumed as the starting water surface. This depth was computed by use of the slope-conveyance method outlined in the user's manual for WSPRO (Shearman, 1990). The slope used was $0.0121 \mathrm{ft} / \mathrm{ft}$ which was the 100 -year discharge water surface slope downstream of the bridge in the Flood Insurance Study for Lincoln, VT (Federal Emergency Management Agency, August 19, 1986).

The surveyed approach section (APTEM) was moved along the approach channel slope $(0.0199 \mathrm{ft} / \mathrm{ft})$ to establish the modelled approach section (APPR1), one bridge length upstream of the upstream face as recommended by Shearman and others (1986). This approach also provides a consistent method for determining scour variables.

For the incipient-overtopping discharge, WSPRO assumes critical depth at the bridge section. A supercritical model was developed for this discharges. After analyzing both the supercritical and subcritical models for each discharge, it can be determined that the water surface profile does pass through critical depth within the bridge opening. Thus, the assumption of critical depth at the bridge is a satisfactory solution. 


\section{Bridge Hydraulics Summary}

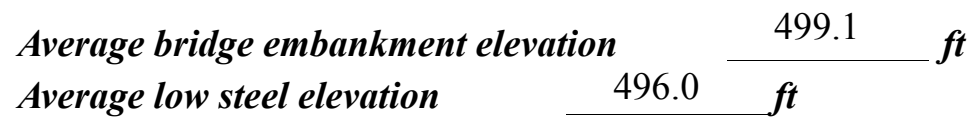

$$
\text { 100-year discharge } \quad 7,960 \quad \mathrm{ft}^{3} / \mathrm{s}
$$

Water-surface elevation in bridge opening $\quad 496.7 \quad f t$

Road overtopping? ___ Y Discharge over road _ $411, \ldots$

Area of flow in bridge opening $\quad 690 \quad \mathrm{ft}^{2}$

Average velocity in bridge opening $10.9 \quad \mathrm{ft} / \mathrm{s}$

$\begin{array}{llll}\text { Maximum WSPRO tube velocity at bridge } & 13.3 \mathrm{ft} / \mathrm{s}\end{array}$

Water-surface elevation at Approach section with bridge 499.3

Water-surface elevation at Approach section without bridge $\quad \overline{494.4}$

Amount of backwater caused by bridge $\quad 4.9$ it

500-year discharge $\quad 11,000 \quad \boldsymbol{f t}^{3} / \mathrm{s}$

Water-surface elevation in bridge opening $\quad 496.0 \mathrm{ft}$

Road overtopping? ___ Y Discharge over road __ $2200 \mathrm{ft}^{3} / \mathrm{s}$

Area of flow in bridge opening $\quad 680 \quad \mathrm{ft}^{2}$

Average velocity in bridge opening $\quad 13.0 \mathrm{ft} / \mathrm{s}$

Maximum WSPRO tube velocity at bridge $\quad 18.0 \_$'s

Water-surface elevation at Approach section with bridge 501.2

Water-surface elevation at Approach section without bridge $\quad 495.8$

Amount of backwater caused by bridge 5.4 .

Incipient overtopping discharge $\quad 7,310 \mathrm{ft}^{3} / \mathrm{s}$

Water-surface elevation in bridge opening $492.2 \quad t$

Area of flow in bridge opening $\quad 455 \quad \mathrm{ft}^{2}$

Average velocity in bridge opening $\quad 16.1 \quad \mathrm{ft} / \mathrm{s}$

Maximum WSPRO tube velocity at bridge $\quad 19.0 \mathrm{ft} / \mathrm{s}$

Water-surface elevation at Approach section with bridge 496.9

Water-surface elevation at Approach section without bridge $494.0^{-}$ Amount of backwater caused by bridge $\quad 2.9$ it 


\section{Scour Analysis Summary}

\section{Special Conditions or Assumptions Made in Scour Analysis}

Scour depths were computed using the general guidelines described in Hydraulic Engineering Circular 18 (Richardson and Davis, 1995). Scour depths were calculated assuming an infinite depth of erosive material and a homogeneous particle-size distribution. The results of the scour analysis are presented in tables 1 and 2 and a graph of the scour depths is presented in figure 8 .

Contraction scour for the incipient roadway-overtopping discharge was computed by use of Laursen's clear-water contraction scour equation (Richardson and others, 1995, p. 32, equation 20). The 100-year and 500-year discharges resulted in unsubmerged orifice flow. Contraction scour at bridges with orifice flow is best estimated by use of the Chang pressureflow scour equation (oral communication, J. Sterling Jones, October 4, 1996). Therefore, contraction scour for these discharges was computed by use of the Chang equation (Richardson and Davis, 1995, p. 145-146). The computed streambed armoring depths suggest that armoring will not limit the depth of contraction scour.

For comparison, contraction scour for the discharges resulting in orifice flow was also computed by use of the Laursen clear-water contraction scour equation and the Umbrell pressure-flow equation (Richardson and Davis, 1995, p. 144) and presented in appendix F. Furthermore, for those discharges resulting in unsubmerged orifice flow, contraction scour was computed by substituting estimates for the depth of flow at the downstream bridge face in the contraction scour equations. Results with respect to these substitutions are provided in appendix F.

Abutment scour was computed by use of the Froehlich equation (Richardson and Davis, 1995, p. 48, equation 28). Variables for the Froehlich equation include the Froude number of the flow approaching the embankments, the length of the embankment blocking flow, and the depth of flow approaching the embankment less any roadway overtopping. 


\section{Scour Results}

$$
\text { 100-yr discharge 500-yr discharge }
$$

Contraction scour:

(Scour depths in feet)

Main channel

Live-bed scour

Clear-water scour

Depth to armoring

Left overbank

Right overbank

Local scour:

Abutment scour

Left abutment

14.0

17.8

$10.1-$

5.9-

11.9-

\section{Right abutment}

Pier scour

Pier 1

Pier 2

Pier 3

Abutments:

\section{Left abutment}

\section{Right abutment}

Piers:

Pier 1

Pier 2

overtopping discharge
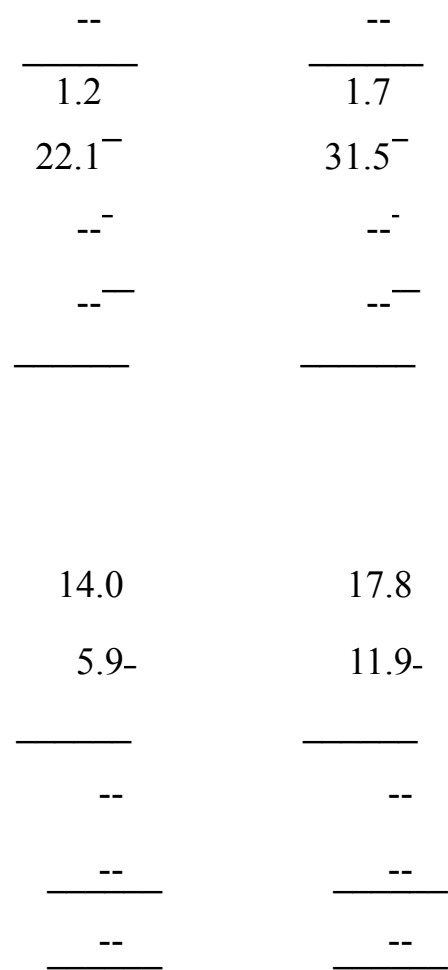

Riprap Sizing

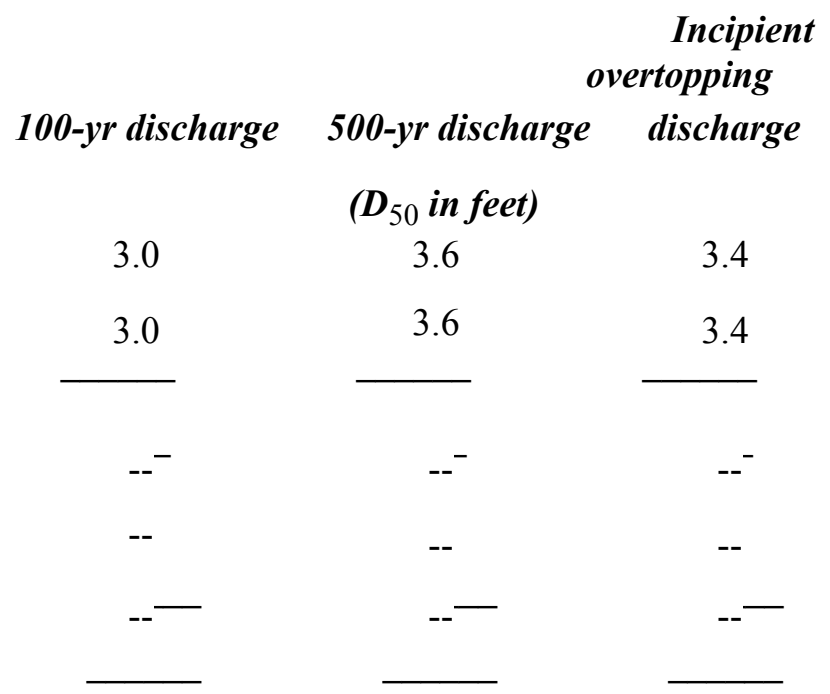




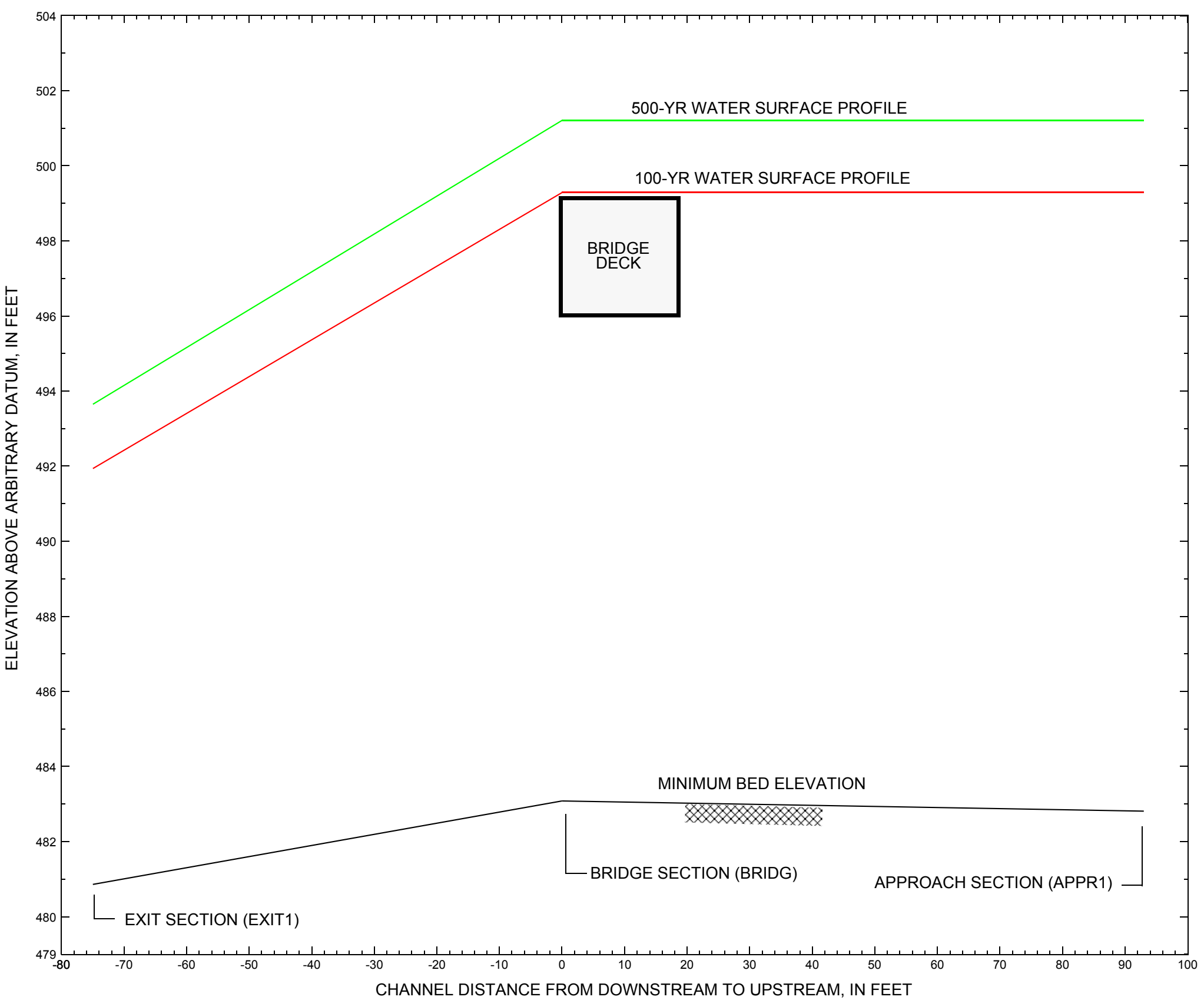

Figure 7. Water-surface profiles for the 100- and 500-yr discharges at structure LINCTH00060046 on Town Highway 6, crossing the New Haven River, Lincoln, Vermont. 


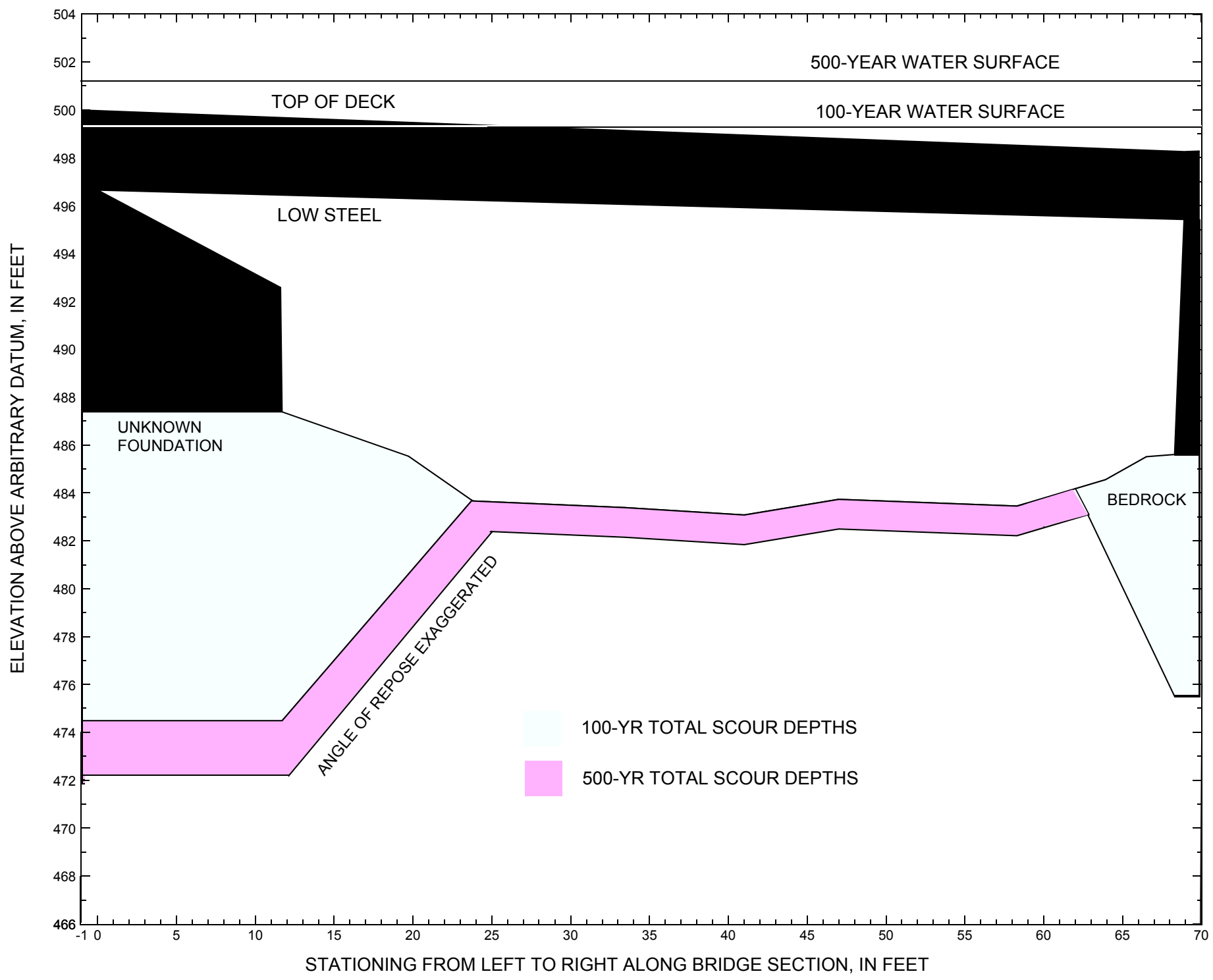

Figure 8. Scour elevations for the 100-yr discharge at structure LINCTH00060046 on Town Highway 6, crossing the New Haven River, Lincoln, Vermont. 
Table 1. Remaining footing/pile depth at abutments for the 100-year discharge at structure LINCTH00060046 on Town Highway 6, crossing the New Haven River, Lincoln, Vermont.

[VTAOT, Vermont Agency of Transportation; --,no data]

\begin{tabular}{|c|c|c|c|c|c|c|c|c|c|c|c|}
\hline Description & Station $^{1}$ & $\begin{array}{l}\text { VTAOT } \\
\text { minimum } \\
\text { low-chord } \\
\text { elevation } \\
\text { (feet) }\end{array}$ & $\begin{array}{c}\text { Surveyed } \\
\text { minimum } \\
\text { low-chord } \\
\text { elevation } \\
\text { (feet) }\end{array}$ & $\begin{array}{c}\text { Bottom of } \\
\text { footing } \\
\text { elevation } \\
\text { (feet) }\end{array}$ & $\begin{array}{c}\text { Channel } \\
\text { elevation at } \\
\text { abutment/ } \\
\text { pier }^{2} \\
\text { (feet) }\end{array}$ & $\begin{array}{l}\text { Contraction } \\
\text { scour depth } \\
\text { (feet) }\end{array}$ & $\begin{array}{l}\text { Abutment } \\
\text { scour } \\
\text { depth } \\
\text { (feet) }\end{array}$ & $\begin{array}{l}\text { Pier } \\
\text { scour } \\
\text { depth } \\
\text { (feet) }\end{array}$ & $\begin{array}{l}\text { Depth of } \\
\text { total scour } \\
\text { (feet) }\end{array}$ & $\begin{array}{c}\text { Elevation of } \\
\text { scour }^{2} \\
\text { (feet) }\end{array}$ & $\begin{array}{c}\text { Remaining } \\
\text { footing/pile } \\
\text { depth } \\
\text { (feet) }\end{array}$ \\
\hline \multicolumn{12}{|c|}{100 -yr. discharge is 7,960 cubic-feet per second } \\
\hline Left abutment & 0.0 & -- & 496.7 & -- & 487.4 & 0.0 & 12.9 & -- & 12.9 & 474.5 & -- \\
\hline Right abutment & 68.9 & -- & 495.4 & -- & 485.6 & 0.0 & 10.1 & -- & 10.1 & 475.5 & -- \\
\hline
\end{tabular}

1.Measured along the face of the most constricting side of the bridge.

2.Arbitrary datum for this study.

Table 2. Remaining footing/pile depth at abutments for the 500-year discharge at structure LINCTH00060046 on Town Highway 6, crossing the New Haven River, Lincoln, Vermont.

[VTAOT, Vermont Agency of Transportation; --, no data]

\begin{tabular}{|c|c|c|c|c|c|c|c|c|c|c|c|}
\hline Description & Station $^{1}$ & $\begin{array}{l}\text { VTAOT } \\
\text { minimum } \\
\text { low-chord } \\
\text { elevation } \\
\text { (feet) }\end{array}$ & $\begin{array}{c}\text { Surveyed } \\
\text { minimum } \\
\text { low-chord } \\
\text { elevation } \\
\text { (feet) }\end{array}$ & $\begin{array}{c}\text { Bottom of } \\
\text { footing } \\
\text { elevation } \\
\text { (feet) }\end{array}$ & $\begin{array}{c}\text { Channel } \\
\text { elevation at } \\
\text { abutment/ } \\
\text { pier }^{2} \\
\text { (feet) }\end{array}$ & $\begin{array}{l}\text { Contraction } \\
\text { scour depth } \\
\text { (feet) }\end{array}$ & $\begin{array}{l}\text { Abutment } \\
\text { scour } \\
\text { depth } \\
\text { (feet) }\end{array}$ & $\begin{array}{l}\text { Pier } \\
\text { scour } \\
\text { depth } \\
\text { (feet) }\end{array}$ & $\begin{array}{l}\text { Depth of } \\
\text { total scour } \\
\text { (feet) }\end{array}$ & $\begin{array}{c}\text { Elevation of } \\
\text { scour }^{2} \\
\text { (feet) }\end{array}$ & $\begin{array}{c}\text { Remaining } \\
\text { footing/pile } \\
\text { depth } \\
\text { (feet) }\end{array}$ \\
\hline \multicolumn{12}{|c|}{500 -yr. discharge is 11,000 cubic-feet per second } \\
\hline Left abutment & 0.0 & -- & 496.7 & -- & 487.4 & 1.2 & 14.0 & -- & 15.2 & 472.2 & -- \\
\hline Right abutment & 68.9 & -- & 495.4 & -- & 485.6 & 1.2 & 5.9 & -- & 7.1 & 478.5 & -- \\
\hline
\end{tabular}

1.Measured along the face of the most constricting side of the bridge.

2.Arbitrary datum for this study. 


\section{SELECTED REFERENCES}

Arcement, G.J., Jr., and Schneider, V.R., 1989, Guide for selecting Manning's roughness coefficients for natural channels and flood plains: U.S. Geological Survey Water-Supply Paper 2339, 38 p.

Barnes, H.H., Jr., 1967, Roughness characteristics of natural channels: U.S. Geological Survey Water-Supply Paper 1849, 213 p.

Benson, M. A., 1962, Factors Influencing the Occurrence of Floods in a Humid Region of Diverse Terrain: U.S. Geological Survey Water-Supply Paper $1580-\mathrm{B}, 64 \mathrm{p}$.

Brown, S.A. and Clyde, E.S., 1989, Design of riprap revetment: Federal Highway Administration Hydraulic Engineering Circular No. 11, Publication FHWA-IP-89-016, 156 p.

Federal Highway Administration, 1983, Runoff estimates for small watersheds and development of sound design: Federal Highway Administration Report FHWA-RD-77-158.

Federal Highway Administration, 1993, Stream Stability and Scour at Highway Bridges: Participant Workbook: Federal Highway Administration Report FHWA-HI-91-011.

Federal Emergency Management Agency, 1986, Flood Insurance Study, Town of Lincoln, Addision County, Vermont: Washington, D.C., August 1986.

Froehlich, D.C., 1989, Local scour at bridge abutments in Ports, M.A., ed., Hydraulic Engineering--Proceedings of the 1989 National Conference on Hydraulic Engineering: New York, American Society of Civil Engineers, p. 13-18.

Hayes, D.C.,1993, Site selection and collection of bridge-scour data in Delaware, Maryland, and Virginia: U.S. Geological Survey Water-Resources Investigation Report 93-4017, 23 p.

Interagency Advisory Committee on Water Data, 1982, Guidelines for determining flood flow frequency: U.S. Geological Survey, Bulletin 17B of the Hydrology Subcommittee, 190 p.

Johnson, C.G. and Tasker, G.D.,1974, Progress report on flood magnitude and frequency of Vermont streams: U.S. Geological Survey Open-File Report 74-130, $37 \mathrm{p}$.

Lagasse, P.F., Schall, J.D., Johnson, F., Richardson, E.V., Chang, F., 1995, Stream Stability at Highway Structures: Federal Highway Administration Hydraulic Engineering Circular No. 20, Publication FHWA-IP-90-014, 144 p.

Laursen, E.M., 1960, Scour at bridge crossings: Journal of the Hydraulics Division, American Society of Civil Engineers, v. 86, no. HY2, p. $39-53$.

Potter, W. D., 1957a, Peak rates of runoff in the Adirondack, White Mountains, and Maine woods area, Bureau of Public Roads

Potter, W. D., 1957b, Peak rates of runoff in the New England Hill and Lowland area, Bureau of Public Roads

Richardson, E.V. and Davis, S.R., 1995, Evaluating scour at bridges: Federal Highway Administration Hydraulic Engineering Circular No. 18, Publication FHWA-IP-90-017, 204 p.

Richardson, E.V., Simons, D.B., and Julien, P.Y., 1990, Highways in the river environment: Federal Highway Administration Publication FHWA-HI90-016.

Ritter, D.F., 1984, Process Geomorphology: W.C. Brown Co., Debuque, Iowa, 603 p.

Shearman, J.O., 1990, User's manual for WSPRO--a computer model for water surface profile computations: Federal Highway Administration Publication FHWA-IP-89-027, 187 p.

Shearman, J.O., Kirby, W.H., Schneider, V.R., and Flippo, H.N., 1986, Bridge waterways analysis model; research report: Federal Highway Administration Publication FHWA-RD-86-108, 112 p.

Talbot, A.N., 1887, The determination of water-way for bridges and culverts.

U.S. Geological Survey, 1963, Bristol, Vermont 7.5 Minute Series quadrangle map: U.S. Geological Survey Topographic Maps, Scale 1:24,000.

U.S. Geological Survey, 1963, South Mountain, Vermont 7.5 Minute Series quadrangle map: U.S. Geological Survey Topographic Maps, Photoinspected 1983, Scale 1:24,000. 


\section{APPENDIX A: \\ WSPRO INPUT FILE}




\section{WSPRO INPUT FILE}

$\mathrm{X}$

GR

GR

GR

XT

GR

GR

GR

GR

GR

GR

GR

*

AS

GT

SA

*

HP 1 BRIDG

HP 2 BRIDG

HP 1 BRIDG

HP 2 RDWAY

HP 1 APPR 1

HP 2 APPR 1

*

HP 1 BRIDG

HP 2 BRIDG

FULLV
U.S. Geological Survey WSPRO Input File linc046.wsp Hydraulic analysis for structure LINCTH00060046 Date: 06-FEB-97 TH006, NEW HAVEN RIVER, LINCOLN, VERMONT ECW

* * 0.0005

$6293055255355151617 \quad 13 \quad 3 * 1514232111124473$

$7960.0 \quad 11000.0 \quad 7310.0$

$\begin{array}{lll}0.0121 & 0.0121 & 0.0121\end{array}$

EXIT1 -75

$-228.4,513.18 \quad-20.1,504.46$

$18.2,485.03 \quad 33.2,483.22$

$59.0,483.23 \quad 60.4,480.86$

$89.4,484.98 \quad 94.2,486.28$

$0.0,489.62$

$4.2,485.68$

$42.0,483.90$

$48.0,482.83$

$68.8,482.69$

$86.3,483.68$

$117.6,497.11$

$138.5,497.34$

$102.8,493.23$

$108.9,497.72$

$166.7,499.48 \quad 219.8,506.87$

0.075

0.060

0.065

$0.0 \quad 108.9$

$0 * * * 0.0248$

$\begin{array}{cccc} & \text { SRD } & \text { LSEL } & \text { XSSKEW } \\ \text { BRIDG } & 0 & 496.04 & 5.0\end{array}$

$0.0,496.65 \quad 11.6,492.58$

$23.8,483.66 \quad 33.4,483.39$

$58.3,483.45 \quad 63.9,484.55$

$68.9,495.42$

$0.0,496.65$

$11.7 \quad 487.39$

$19.7,485.54$

$41.0,483.08$

$47.0,483.73$

$66.5,485.51$

$68.3,485.61$

BRTYPE BRWDTH WWANGL WWWID

137.1 * * $34.4 \quad 7.5$

0.055

SRD EMBWID IPAVE

$12 \quad 21.2$

$-332.2,524.63-218.6,513.79$

$-149.5,510.98-106.2,508.21$

$-40.6,504.46$

$0.0,499.97$

$83.0,498.26$

$119.9,497.99$

$139.7,509.53$

APTEM 82

$-182.9,510.94$

$-100.2,509.82$

$-19.7,506.33$

$-7.0,496.03$

$-3.2,493.93$

$0.0,489.52$

$16.4,486.17$

$17.2,484.26$

$18.7,484.35$

$18.8,483.90$

$22.3,482.84$

$26.1,483.91$

$27.6,482.59$

$39.1,483.90$

$44.0,483.76$

$53.7,484.95$

$57.6,485.60$

$60.0,484.90$

$76.0,495.97$

$84.4,497.40$

$60.5,485.89$

$65.8,487.42$

$138.5,513.61$

$106.3,499.57$

$113.8,498.28$ 


\section{APPENDIX B: \\ WSPRO OUTPUT FILE}


WSPRO OUTPUT FILE

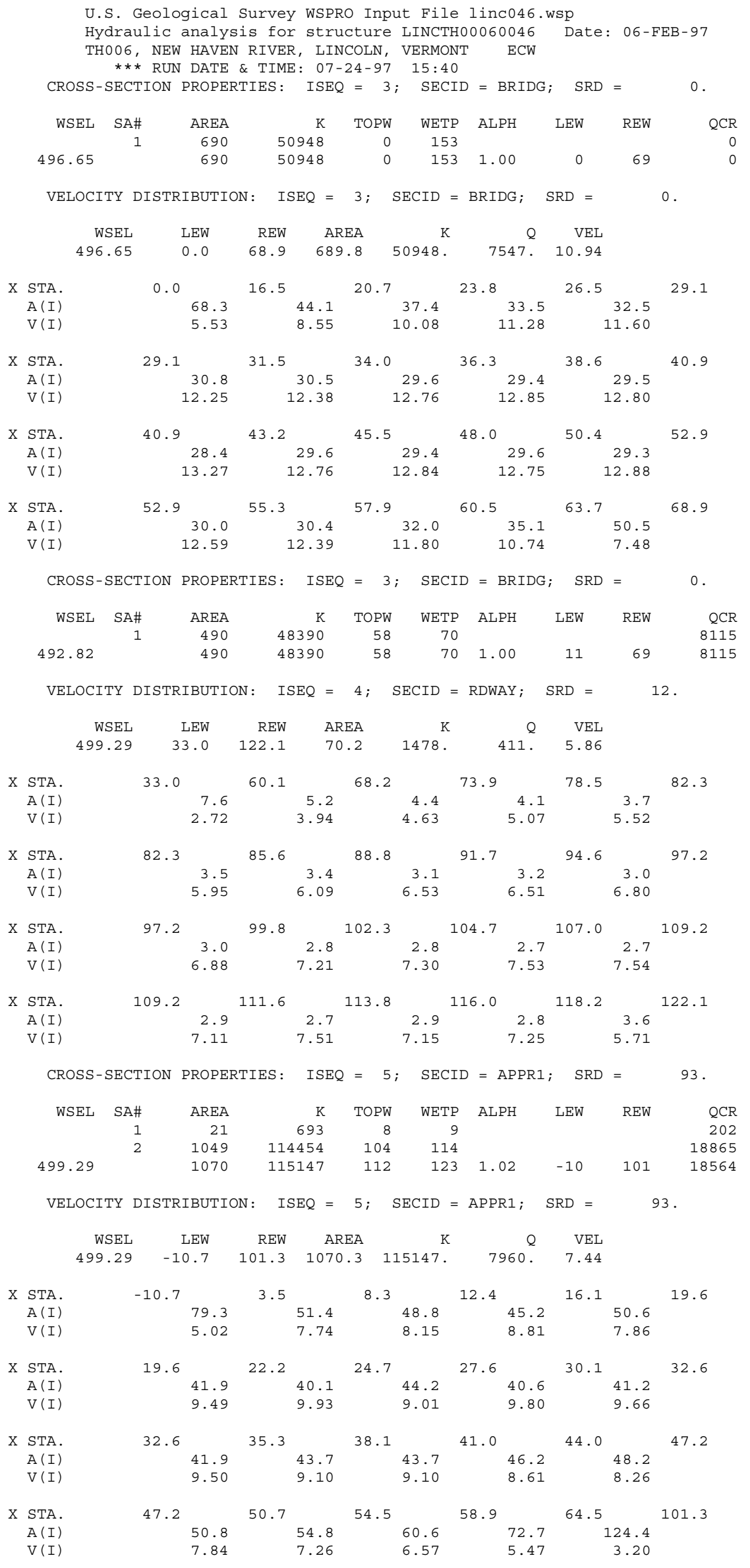


WSPRO OUTPUT FILE (continued)

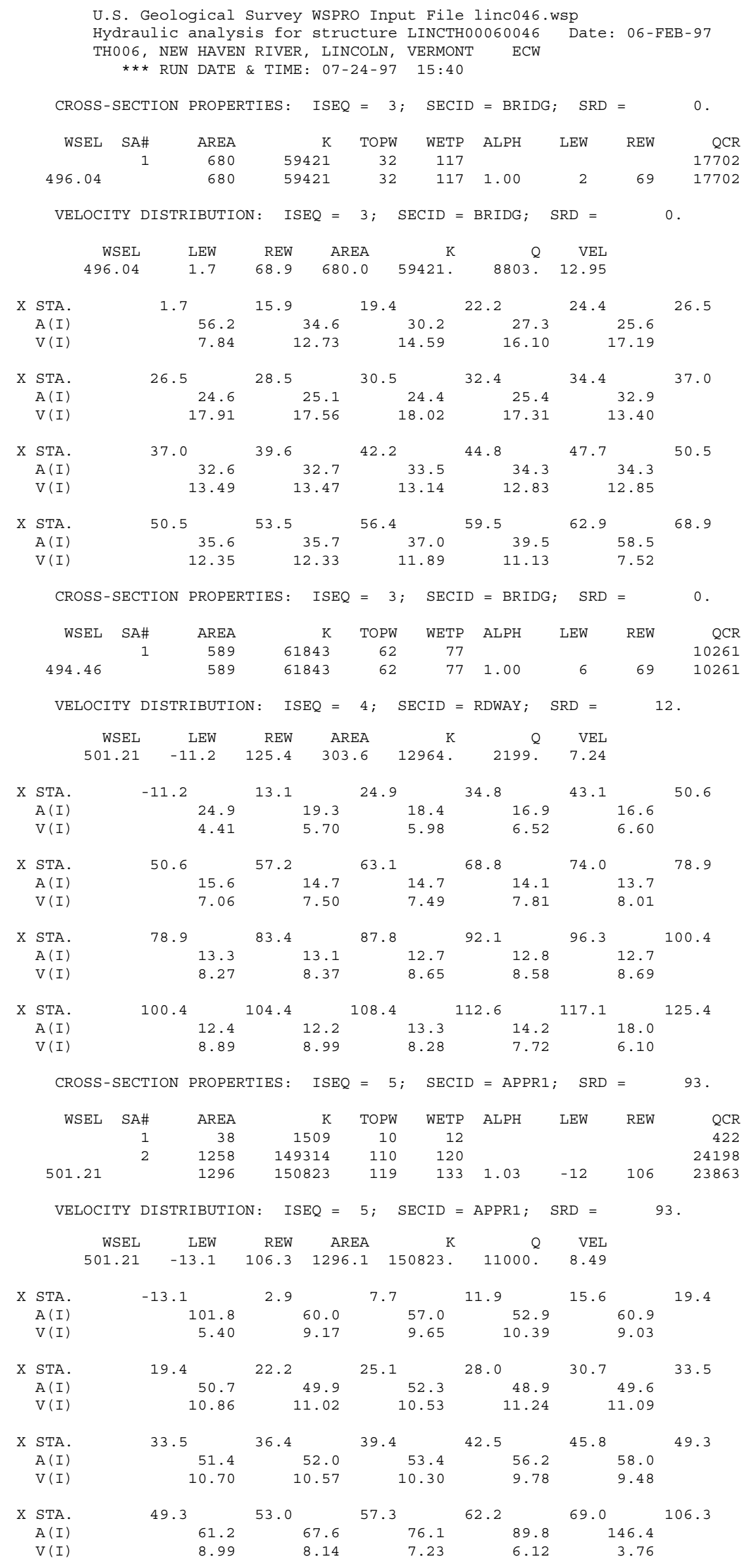


WSPRO OUTPUT FILE (continued)

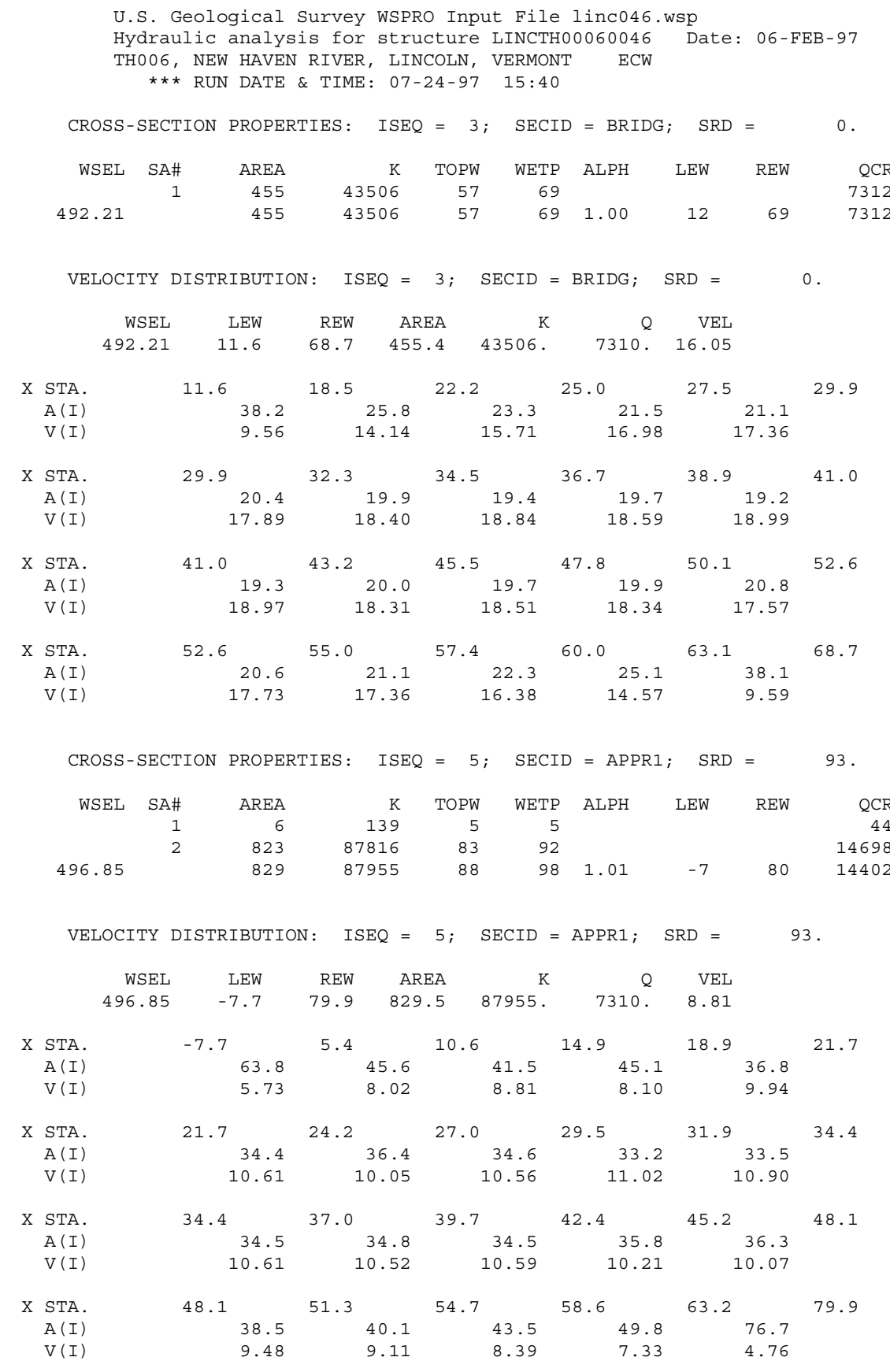


WSPRO OUTPUT FILE (continued)

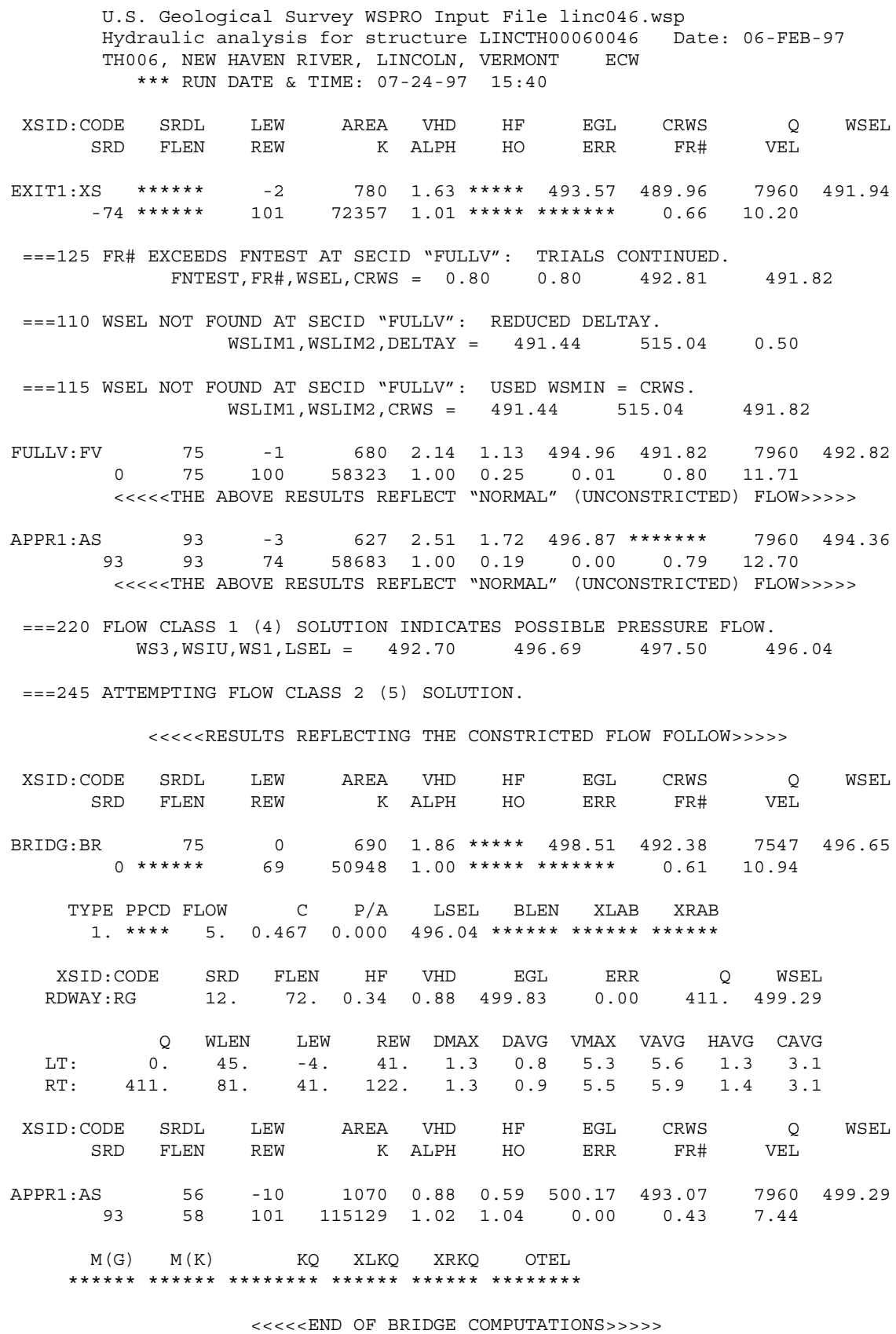

FIRST USER DEFINED TABLE.

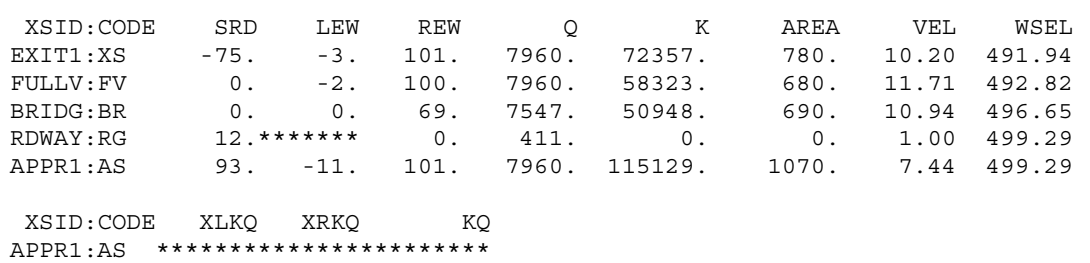

SECOND USER DEFINED TABLE.

\begin{tabular}{|c|c|c|c|c|c|c|c|c|c|}
\hline$E$ & CRWS & FR\# & YMIN & YMAX & $\mathrm{HF}$ & $\mathrm{HO}$ & VHD & EGL & \\
\hline EIT1:XS & 489.96 & .66 & 80.86 & $13.18 *$ & & & 1.63 & 93.57 & \\
\hline UL & 1.82 & 80 & 2 & 5.04 & 1.13 & 0.25 & .14 & 4.96 & 92 \\
\hline$R$ & 8 & $\perp$ & & $96.65 *$ & 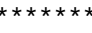 & 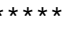 & 36 & 51 & \\
\hline & & & & 53 & 0 & $\star \star \star \star \star \star$ & 8 & 83 & \\
\hline PPR1:AS & 493.07 & 0.43 & 482.81 & 513.83 & 0.59 & 1.04 & 0.88 & 500.17 & 99 \\
\hline
\end{tabular}


WSPRO OUTPUT FILE (continued)

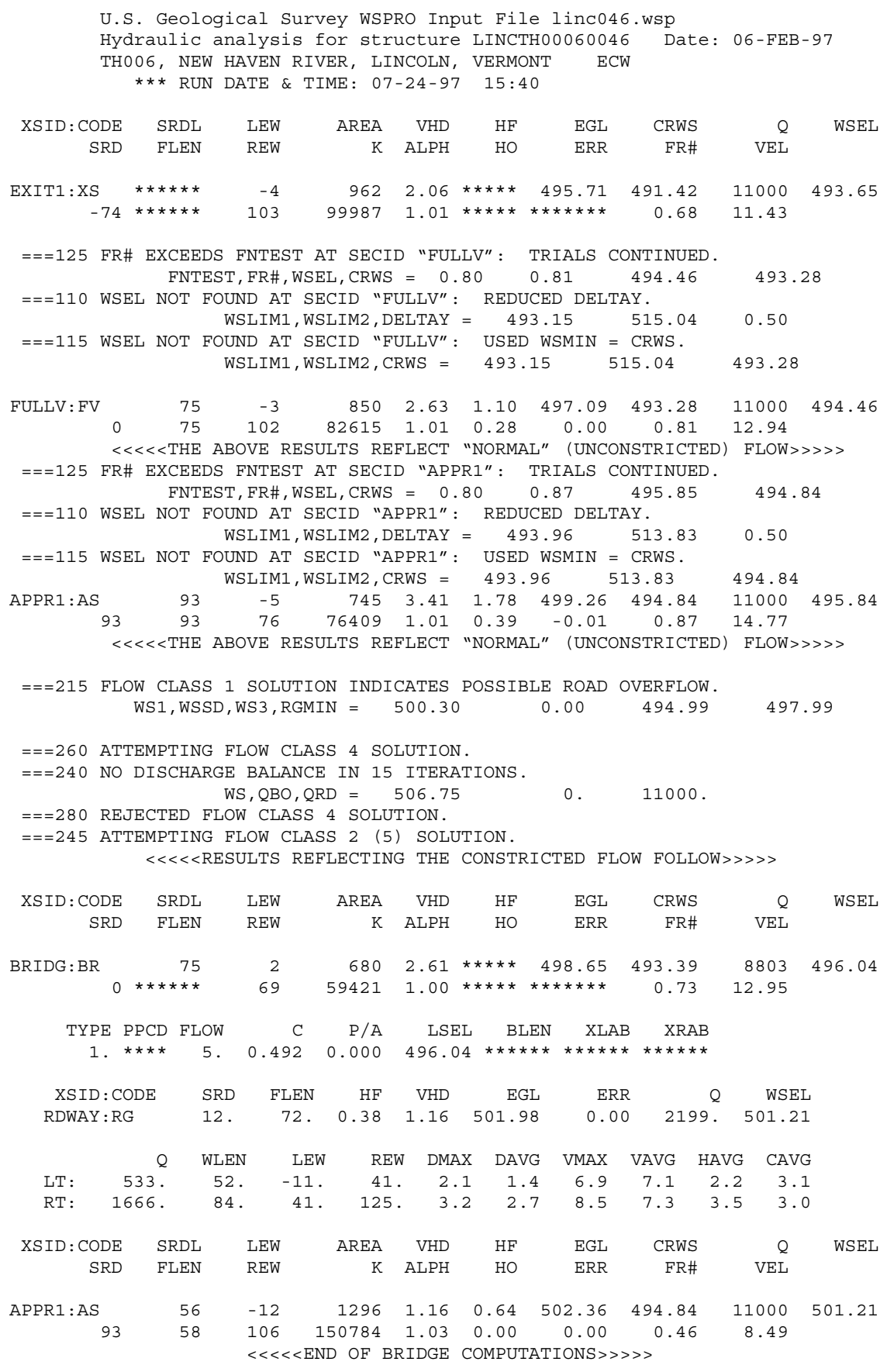

FIRST USER DEFINED TABLE.

\begin{tabular}{|c|c|c|c|c|c|c|c|c|}
\hline XSID : CODE & SRD & LEW & REW & 0 & $\mathrm{~K}$ & AREA & VEL & WSEL \\
\hline EXIT1:XS & -75 & -5 . & 103. & 11000. & 99987. & 962. & 11.43 & 493.65 \\
\hline FULLV : FV & 0 . & -4 & 102. & 11000. & 82615 . & 850. & 12.94 & 494.46 \\
\hline BRIDG : BR & 0 . & 2 . & 69. & 8803. & 59421. & 680. & 12.95 & 496.04 \\
\hline RDWAY : RG & 12 * * & 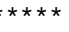 & 533. & 2199. & 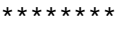 & 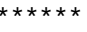 & 1.00 & 501.21 \\
\hline APPR1: AS & 93. & -13 & 106. & 11000. & 150784 . & 1296. & 8.49 & 501.21 \\
\hline XSID : CODE & XLKQ & XRKQ & & & & & & \\
\hline
\end{tabular}

SECOND USER DEFINED TABLE.

$\begin{array}{lcrrrrrrrr}\text { XSID : CODE } & \text { CRWS } & \text { FR\# } & \text { YMIN } & \text { YMAX } & \text { HF } & \text { HO } & \text { VHD } & \text { EGL } & \text { WSEL } \\ \text { EXIT1:XS } & 491.42 & 0.68 & 480.86 & 513.18 * * * * * * * * * * & 2.06 & 495.71 & 493.65 \\ \text { FULLV:FV } & 493.28 & 0.81 & 482.72 & 515.04 & 1.10 & 0.28 & 2.63 & 497.09 & 494.46 \\ \text { BRIDG : BR } & 493.39 & 0.73 & 483.08 & 496.65 * * * * * * * * * * & 2.61 & 498.65 & 496.04 \\ \text { RDWAY:RG } & * * * * * * * * * * * * * * * & 497.99 & 524.63 & 0.38 * * * * * * & 1.16 & 501.98 & 501.21 \\ \text { APPR1:AS } & 494.84 & 0.46 & 482.81 & 513.83 & 0.64 & 0.00 & 1.16 & 502.36 & 501.21\end{array}$


WSPRO OUTPUT FILE (continued)

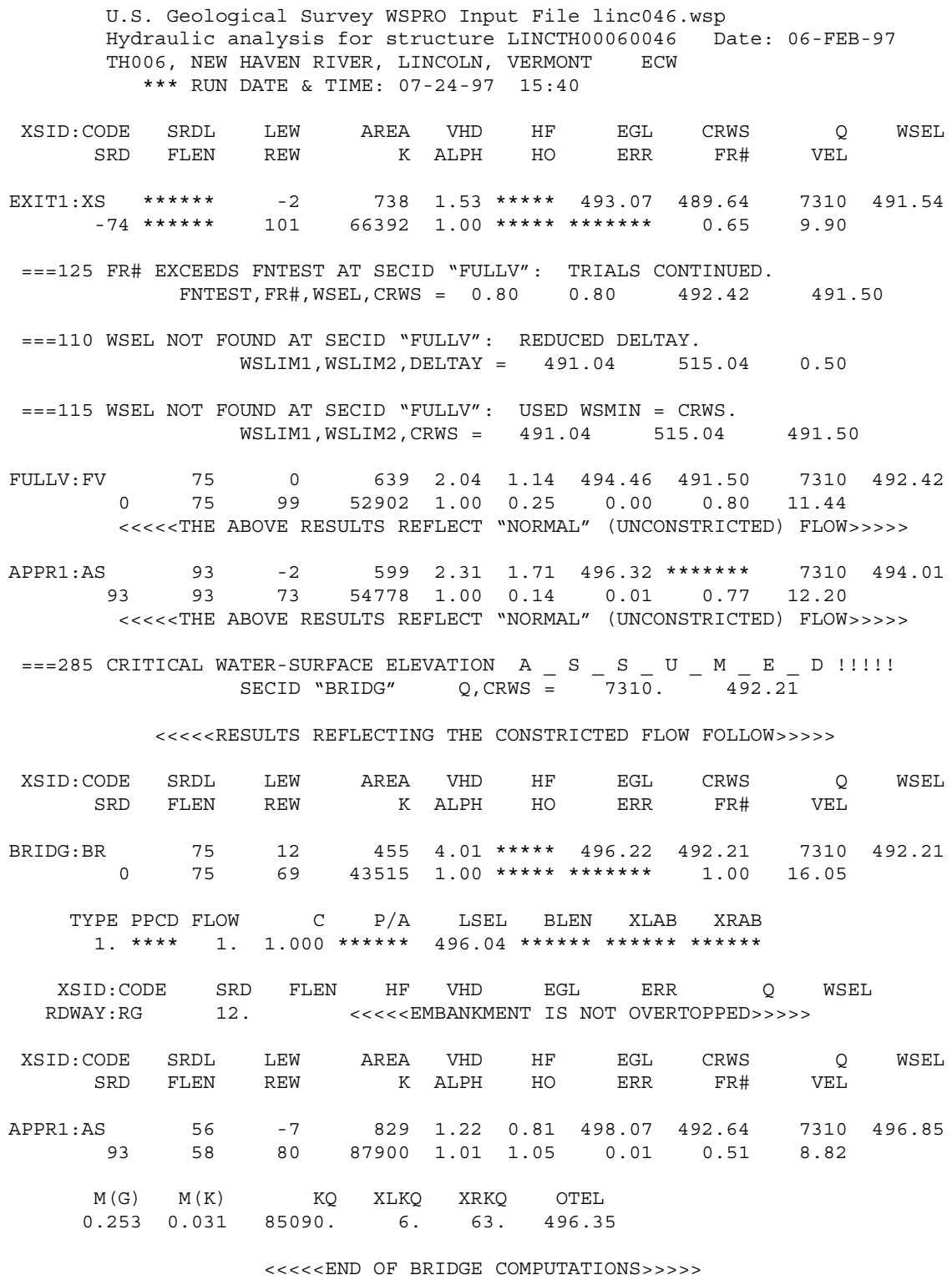

FIRST USER DEFINED TABLE.

\begin{tabular}{|c|c|c|c|c|c|c|c|c|}
\hline XSID: CODE & SRD & LEW & REW & $Q$ & $\mathrm{~K}$ & AREA & VEL & WSEL \\
\hline EXIT1:XS & -75 & -3 . & 101. & 7310. & 66392. & 738. & 9.90 & 491.54 \\
\hline FULLV : FV & 0 . & -1 & 99. & 7310. & 52902 . & 639. & 11.44 & 492.42 \\
\hline BRIDG : BR & 0 . & 12 . & 69. & 7310. & 43515 . & 455. & 16.05 & 492.21 \\
\hline RDWAY : RG & \multicolumn{3}{|c|}{$12 . * * \star * * * * * * * * \star * *$} & \multicolumn{3}{|c|}{ 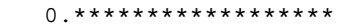 } & \multicolumn{2}{|c|}{$1.00 * * * * * * * *$} \\
\hline APPR 1 : AS & 93. & -8 . & 80 . & 7310. & 87900. & 829. & 8.82 & 496.85 \\
\hline XSID : CODE & XLKQ & $\mathrm{XRKQ}$ & & & & & & \\
\hline APPR $1:$ AS & 6 . & 63. & 8509 & & & & & \\
\hline
\end{tabular}

SECOND USER DEFINED TABLE.

$\begin{array}{lrrrrrrrrr}\text { XSID :CODE } & \text { CRWS } & \text { FR\# } & \text { YMIN } & \text { YMAX } & \text { HF } & \text { HO } & \text { VHD } & \text { EGL } & \text { WSEL } \\ \text { EXIT1:XS } & 489.64 & 0.65 & 480.86 & 513.18 * * * * * * * * * * * & 1.53 & 493.07 & 491.54 \\ \text { FULLV:FV } & 491.50 & 0.80 & 482.72 & 515.04 & 1.14 & 0.25 & 2.04 & 494.46 & 492.42 \\ \text { BRIDG:BR } & 492.21 & 1.00 & 483.08 & 496.65 * * * * * * * * * * * & 4.01 & 496.22 & 492.21 \\ \text { RDWAY:RG } & * * * * * * * * * * * * * * & 497.99 & 524.63 * * * * * * * * * * * * * * * * * * * * * * * * * * * \\ \text { APPR1:AS } & 492.64 & 0.51 & 482.81 & 513.83 & 0.81 & 1.05 & 1.22 & 498.07 & 496.85 \\ \text { ER } & & & & & & & & & \end{array}$

NORMAL END OF WSPRO EXECUTION. 


\section{APPENDIX C:}

\section{BED-MATERIAL PARTICAL-SIZE DISTRIBUTION}




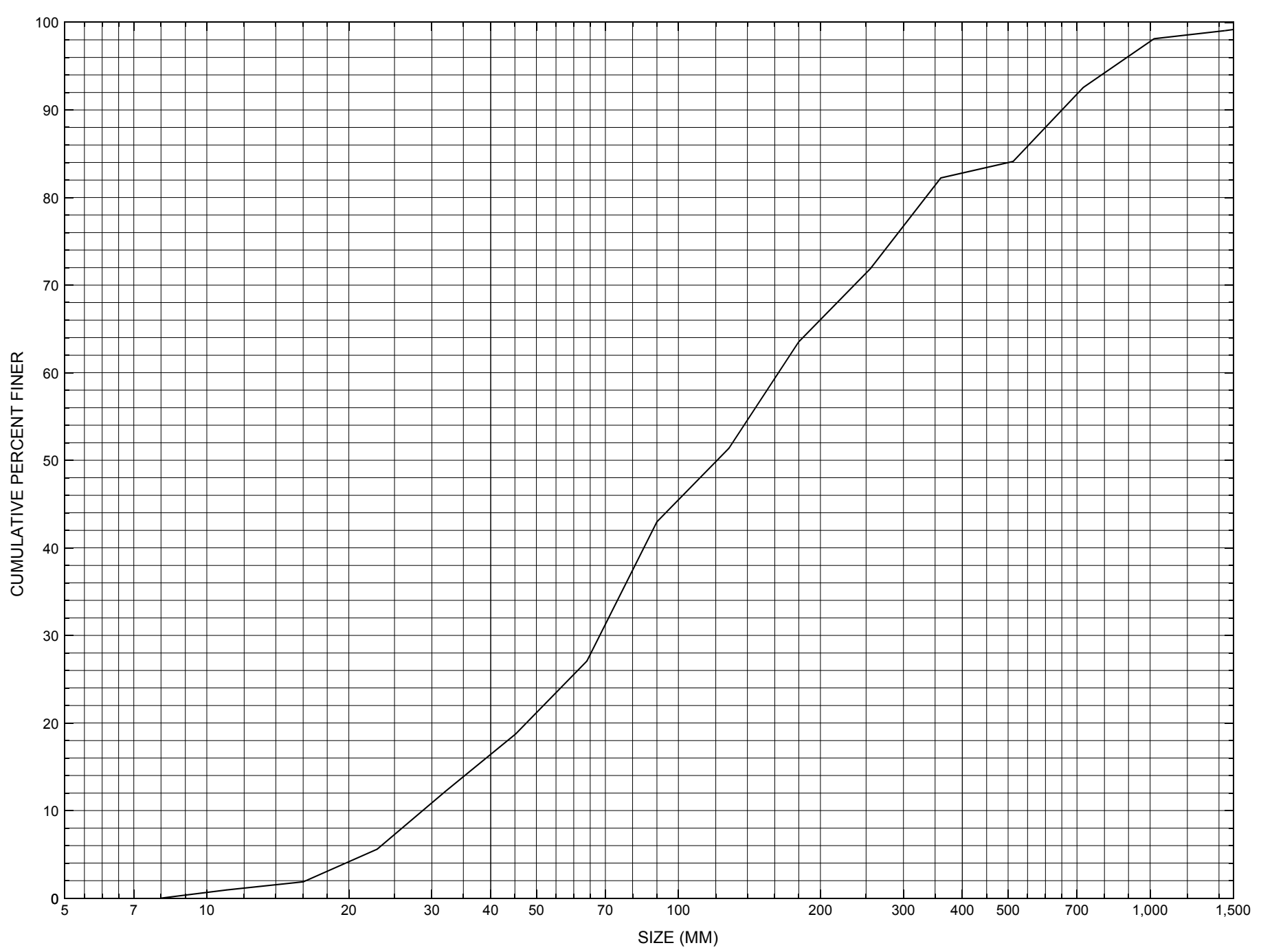

Appendix C. Bed material particle-size distribution for a pebble count in the channel approach of structure LINCTH00060046, in Lincoln, Vermont. 


\section{APPENDIX D: \\ HISTORICAL DATA FORM}




\section{Structure Number LINCTH00060046}

\section{General Location Descriptive}

Data collected by (First Initial, Full last name) $\underline{\mathbf{L}}$. Medalie

Date $(M M / D D / Y Y)+12 / 14 / \underline{95}$

Highway District Number (I - 2; nn) $\mathbf{0 5}$

Town (FIPS place code; I - 4; nnnnn) $\mathbf{4 0 0 7 5}$

Waterway ( $($ - 6) NEW HAVEN RIVER

Route Number C3006

Topographic Map South Mountain

Latitude (I - 16; nnnn.n) $\mathbf{4 4 0 7 1}$
County (FIPS county code; I - 3; nnn)

Mile marker (I - 11; nnn.nnn) $\mathbf{0 0 0 0 0 0}$

Road Name (I - 7): -

Vicinity (I - 9)@JCT W CL2 TH1

Hydrologic Unit Code: 2010002

Longitude (i - 17; nnnnn.n) $\mathbf{7 3 0 1 2}$

\section{Select Federal Inventory Codes}

FHWA Structure Number $(I$ - 8) 10011000460110

Maintenance responsibility $(I-21 ; n n) \quad \mathbf{0 3}$

Year built (I - 27; YYYY) 1919

Average daily traffic, ADT (I - 29; nnnnnn) 000200

Year of ADT (I - 30; YY) $\mathbf{9 2}$

Opening skew to Roadway $(I-34 ; n n)$

Operational status $(I-41 ; X) \mathbf{P}$

Structure type (I - 43; nnn) $\mathbf{3 1 0}$

Approach span structure type $(I-44 ; n n n)$ 000

Number of spans (I - 45; nnn) $\mathbf{0 0 1}$

Number of approach spans (I - 46; nnnn) $\mathbf{0 0 0 0}$

Comments:

According to the structural inspection report dated 11/14/94, the structure is a medium to heavy membered steel pony truss. The abutments and backwalls are concrete. The abutments have been poured on the embankments behind the faces of the original concrete and the stone abutments which are still in place, acting as channel protection. A low, coarse gravel bar at the Left abutments blocks a third of the channel flow. Ledge outcrops are showing in the channel. The wingwalls on the old abutments are cracked and spalled. According to a sketch dated 12/7/90, the Right abutment has extensive spalling and at least 3 sections of undermining, from 6"-2' under, 4-8" deep, and 1-3' long sections. 


\section{Bridge Hydrologic Data}

Is there hydrologic data available? $\underline{\mathbf{N}}$ if No, type ctrl-n $h \quad$ VTAOT Drainage area $\left(m i^{2}\right)$ : -

Terrain character:

Stream character \& type: -

Streambed material:

Discharge Data (cfs):

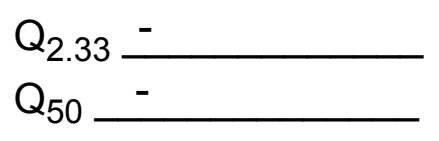

Record flood date $(M M / D D / Y Y):-{ }^{\prime}-\frac{1}{\text { Velocity }}$ at $\mathrm{Q}-$
Estimated Discharge $(c f s):-$

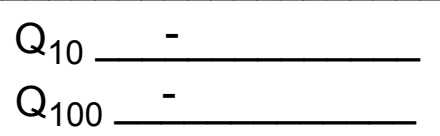

$\mathrm{Q}_{25}$

Water surface elevation $(f t):-$ $(f t / s):$

Ice conditions (Heavy, Moderate, Light) : -

Debris (Heavy, Moderate, Light):

The stage increases to maximum highwater elevation (Rapidly, Not rapidly):

The stream response is (Flashy, Not flashy):

Describe any significant site conditions upstream or downstream that may influence the stream's stage: -

Watershed storage area (in percent):

The watershed storage area is: - (1-mainly at the headwaters; 2- uniformly distributed; 3-immediatly upstream oi the site)

Water Surface Elevation Estimates for Existing Structure:

\begin{tabular}{|l|l|l|l|l|l|}
\hline Peak discharge frequency & $Q_{2.33}$ & $Q_{10}$ & $Q_{25}$ & $Q_{50}$ & $Q_{100}$ \\
Water surface elevation (ft)) & - & - & - & - & - \\
Velocity (ft/sec) & - & - & - & - & - \\
\hline
\end{tabular}

Long term stream bed changes: -

Is the roadway overtopped below the $\mathrm{Q}_{100}$ ? (Yes, No, Unknown): $\mathbf{U}$ Frequency: -

Relief Elevation $(f t)$ :

Discharge over roadway at $\mathrm{Q}_{100}\left(\mathrm{ft}^{3} / \mathrm{sec}\right)$ :

Are there other structures nearby? (Yes, No, Unknown):

Upstream distance (miles):

Town: If No or Unknown, type ctrl-n os

Highway No. : Structure No. : Year Built:

Clear span (ft): Clear Height $(f t)$ : Full Waterway $\left(f^{2}\right)$ : 
Downstream distance (miles): Town: Year Built:

Highway No. : Structure No. : Structure Type:

Clear span $(f t):$ Clear Height $(f t)$ : Full Waterway $\left(f^{2}\right):$

Comments:

\section{USGS Watershed Data}

Watershed Hydrographic Data

Drainage area $(D A) \stackrel{45.87}{4 \mathrm{mi}^{2}}$

Watershed storage (ST) 0.07

Bridge site elevation 880

Main channel length 11.36 $\mathrm{ft}$ $\%$ $10 \%$ channel length elevation $\mathbf{9 4 0}$ $\mathrm{ft} \quad 85 \%$ channel length elevation $\mathrm{ft}$

Main channel slope $(S)$

(S) 142.01 $\mathrm{ft} / \mathrm{mi}$

Watershed Precipitation Data

Average site precipitation in Average headwater precipitation in

Maximum 2yr-24hr precipitation event $(124,2)$ in

Average seasonal snowfall (Sn) $\mathrm{ft}$ 


\section{Bridge Plan Data}

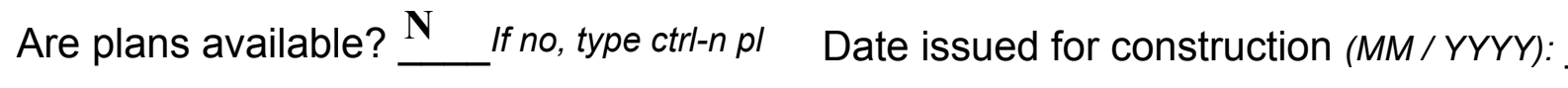

Project Number

Minimum channel bed elevation:

Low superstructure elevation: USLAB DSLAB USRAB DSRAB Benchmark location description:

NO BENCKMARK INFORMATION

Reference Point (MSL, Arbitrary, Other): Datum (NAD27, NAD83, Other):

Foundation Type: 4

If 1 : Footing Thickness

If 2: Pile Type: (1-Wood; 2-Steel or metal; 3-Concrete)

(1-Spreadfooting; 2-Pile; 3- Gravity; 4-Unknown)

If 3 : Footing bottom elevation:

Is boring information available? $\mathbf{N}$ Foundation Material Type: $\mathbf{3}$ If no, type ctrl-n bi Number of borings taken:

Approximate pile driven length: -

Briefly describe material at foundation bottom elevation or around piles:

NO DRILL BORING INFORMATION

Comments: 


\section{Cross-sectional Data}

Is cross-sectional data available? $\mathbf{N}$ If no, type ctrl-n xs

Source (FEMA, VTAOT, Other)? -

Comments: NO CROSS SECTIONAL INFORMATION

\begin{tabular}{|l|l|l|l|l|l|l|l|l|l|l|l|}
\hline Station & & - & - & - & - & - & - & - & - & - & - \\
\hline Feature & - & - & - & - & - & - & - & - & - & - & - \\
\hline $\begin{array}{l}\text { Low cord } \\
\text { elevation }\end{array}$ & - & - & - & - & - & - & - & - & - & - & - \\
\hline $\begin{array}{l}\text { Bed } \\
\text { elevation }\end{array}$ & - & - & - & - & - & - & - & - & - & - & - \\
\hline $\begin{array}{l}\text { Low cord to } \\
\text { bed length }\end{array}$ & - & - & - & - & - & - & - & - & - & - & - \\
\hline Station & - & - & - & - & - & - & - & - & - & - & - \\
\hline Feature & - & - & - & - & - & - & - & - & - & - & - \\
\hline $\begin{array}{l}\text { Low cord } \\
\text { elevation }\end{array}$ & - & - & - & - & - & - & - & - & - & - & - \\
\hline $\begin{array}{l}\text { Bed } \\
\text { elevation }\end{array}$ & - & - & - & - & - & - & - & - & - & - & - \\
\hline $\begin{array}{l}\text { Low cord to } \\
\text { bed length }\end{array}$ & - & - & - & - & - & - & - & - & - & - & - \\
\hline
\end{tabular}

Source (FEMA, VTAOT, Other)?

Comments: -

\begin{tabular}{|l|l|l|l|l|l|l|l|l|l|l|l|}
\hline Station & & - & - & - & - & - & - & - & - & - & - \\
\hline Feature & - & - & - & - & - & - & - & - & - & - & - \\
\hline $\begin{array}{l}\text { Low cord } \\
\text { elevation }\end{array}$ & - & - & - & - & - & - & - & - & - & - & - \\
\hline $\begin{array}{l}\text { Bed } \\
\text { elevation }\end{array}$ & - & - & - & - & - & - & - & - & - & - & - \\
\hline $\begin{array}{l}\text { Low cord to } \\
\text { bed length }\end{array}$ & - & - & - & - & - & - & - & - & - & - & - \\
\hline Station & - & - & - & - & - & - & - & - & - & - & - \\
\hline Feature & - & - & - & - & - & - & - & - & - & - & - \\
\hline $\begin{array}{l}\text { Low cord } \\
\text { elevation }\end{array}$ & - & - & - & - & - & - & - & - & - & - & - \\
\hline $\begin{array}{l}\text { Bed } \\
\text { elevation }\end{array}$ & - & - & - & - & - & - & - & - & - & - & - \\
\hline $\begin{array}{l}\text { Low cord to } \\
\text { bed length }\end{array}$ & - & - & - & - & - & - & - & - & - & - & - \\
\hline
\end{tabular}




\section{APPENDIX E: \\ LEVEL I DATA FORM}


U. S. Geological Survey

Bridge Field Data Collection and Processing Form

Qa/Qc Check by: RB Date: $2 / 6 / 97$

\section{Structure Number LINCTH00060046}

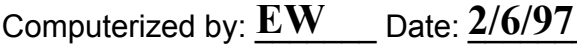

Reviewd by: $\quad$ EW Date: $\underline{4 / 2 / 97}$

\section{A. General Location Descriptive}

1. Data collected by (First Initial, Full last name) E. WILD

2. Highway District Number $\mathbf{0 5}$

County ADDISON (001)

Waterway $(I$ - 6) NEW HAVEN RIVER

Route Number C3006

Date $(M M / D D / Y Y) \underline{06} / 13 / 1996$

3. Descriptive comments:

Mile marker $\mathbf{0}$

Town LINCOLN (40075)

Road Name YORK HILL ROAD

Hydrologic Unit Code: $\mathbf{0 2 0 1 0 0 0 2}$

Bridge is located at junction with CL2 TH1. The structure is a medium to heavy membered steel pony truss.

\section{B. Bridge Deck Observations}
4. Surface cover.
RBUS 6
LBDS *6
RBDS 2
Overall 6

(2b us,ds,lb,rb: 1- Urban; 2- Suburban; 3- Row crops; 4- Pasture; 5- Shrub- and brushland; 6- Forest; 7- Wetland)
5. Ambient water surface... US $\underline{2}$
UB 2
DS 2
(1- pool; 2- riffle)

6. Bridge structure type 1 (1- single span; 2- multiple span; 3- single arch; 4- multiple arch; 5-cylindrical culvert; 6- box culvert; or 7- other)
7. Bridge length $\mathbf{8 5}$
(feet)
Span length $\underline{\mathbf{8 0}}$
(feet)
Bridge width 21.2 (feet)

\section{Road approach to bridge:}
8. LB 2 RB $\underline{0}$
( 0 even, 1- lower, 2- higher)
9. LB_
RB 1
(1- Paved, 2- Not paved)

10. Embankment slope (run / rise in feet / foot)

US left

US right

\begin{tabular}{|c|c|c|c|}
\hline \multicolumn{2}{|c|}{ Protection } & \multirow{2}{*}{ 13.Erosion } & 14.Severity \\
\hline 11.Type & 12.Cond. & $\underline{\mathbf{2}}$ & $\underline{\mathbf{2}}$ \\
\hline $\mathbf{3}$ & $\mathbf{2}$ & $\underline{\mathbf{2}}$ & $\underline{\mathbf{1}}$ \\
\hline $\mathbf{3}$ & $\mathbf{1}$ & $\underline{\mathbf{2}}$ & $\underline{\mathbf{2}}$ \\
\hline $\mathbf{3}$ & $\underline{\mathbf{2}}$ & $\underline{\mathbf{2}}$ \\
\hline $\mathbf{2}$ & $\underline{\mathbf{2}}$ & $\underline{\mathbf{2}}$ \\
\hline
\end{tabular}

Bank protection types: 0- none; 1- < 12 inches,

2- $<36$ inches; $3-<48$ inches;

4- < 60 inches; 5- wall / artificial levee

Bank protection conditions: 1- good; 2- slumped;

3- eroded; 4- failed

Erosion: 0 - none; 1- channel erosion; 2 -

road wash; 3- both; 4- other

Erosion Severity: 0 - none; 1- slight; 2- moderate; 3- severe

\section{Channel approach to bridge (BF):}

15. Angle of approach: 15

16. Bridge skew: 25

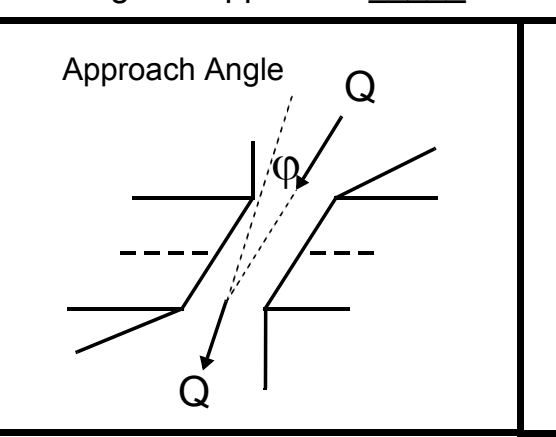

17. Channel impact zone 1:

Where? RB (LB, RB)

Exist? $\mathbf{Y}(Y$ or $N)$ Bridge Skew Angle

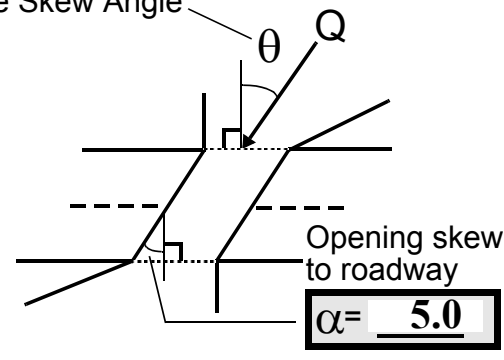

Range? 300 feet US

Severity $\mathbf{0}$

Channel impact zone 2:

(US, UB, DS) to 95 feet $\underline{\mathbf{D S}}$

Where? LB (LB, RB)

Exist? $\underline{\mathbf{Y}}(\mathrm{Y}$ or $N)$

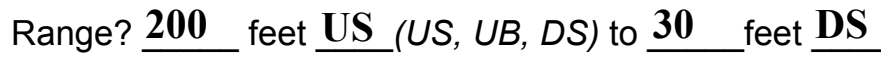

Impact Severity: 0- none to very slight; 1-Slight; 2- Moderate; 3- Severe 
18. Bridge Type: 1a

1a- Vertical abutments with wingwalls

1 b- Vertical abutments without wingwalls

2- Vertical abutments and wingwalls, sloping embankment Wingwalls perpendicular to abut. face

3- Spill through abutments

4- Sloping embankment, vertical wingwalls and abutments

Wingwall angle less than $90^{\circ}$.

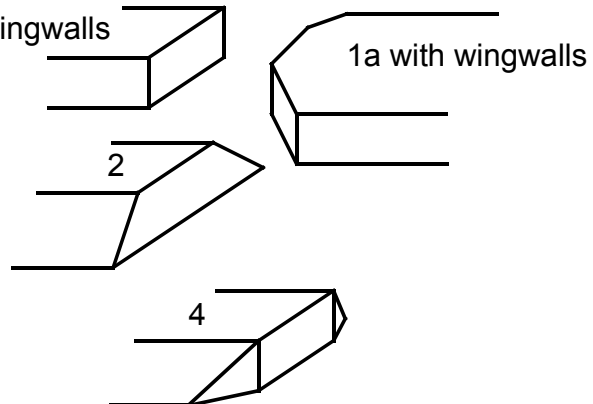

19. Bridge Deck Comments (surface cover variations, measured bridge and span lengths, bridge type variations, approach overflow width, etc.)

4: On the upstream and downstream left overbanks, there are homes with yards and many trees. The upstream right bank is all forest, with the exception of the immediate bank where Town Highway 1 is parallel with stream. The downstream right overbank surface cover is Town Highway 1 along immediate bank and suburban (buildings, grass and less than fifty percent pavement) beyond.

7: Values are from Vermont AOT database. Measurements during site visit: bridge length $=83.4$ feet and bridge width $=21.0$ feet.

\section{Upstream Channel Assessment}

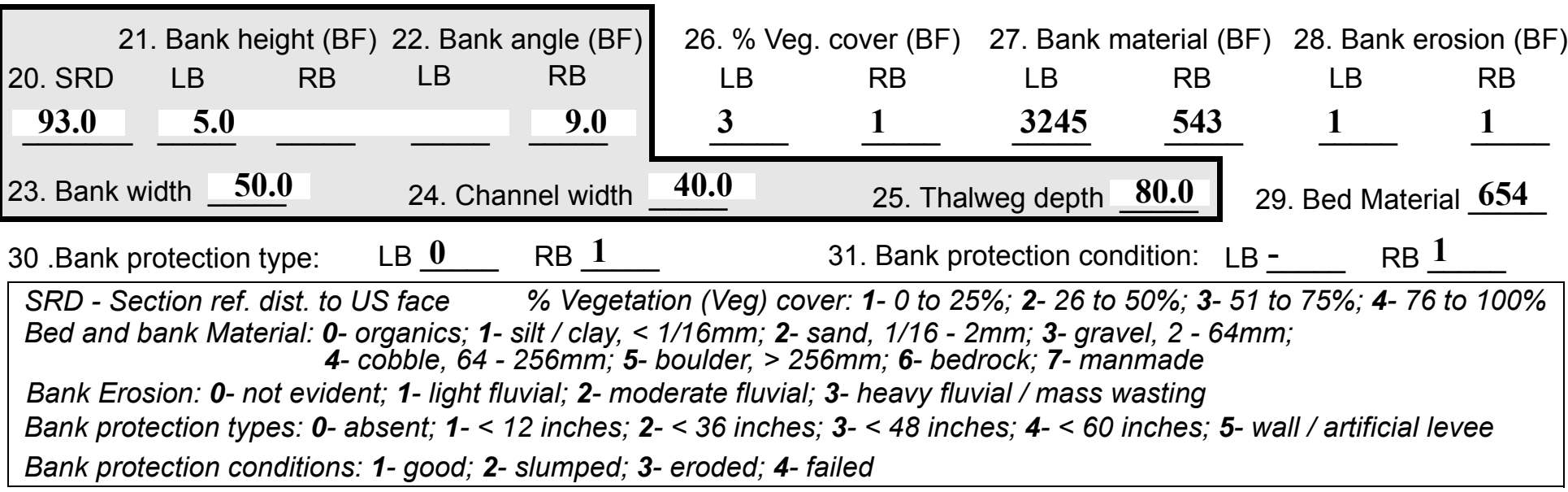

32. Comments (bank material variation, minor inflows, protection extent, etc.):

29: Bed material is mostly bedrock from approximately 300 feet upstream to 49 feet upstream. The bedrock comprises about $65 \%$ of the channel from the right bank.

30: Protection is predominately small material (6-8 inches) with sparse boulders. 

feet US (US, UB) to 2.5 feet DS (US, UB, DS) positioned $\mathbf{0}$ $\%$ LB to 35 $\%$ RB

37. Material: $\mathbf{5 4 3 2 0 1}$

38. Point or side bar comments (Circle Point or Side; Note additional bars, material variation, status, etc.):

37: Point bar material grades from large boulder, gravel, grass and ferns upstream (320 feet upstream to 30 feet upstream) to cobbles, gravel and sand downstream (30 feet upstream to 2.5 feet downstream).

39. Is a cut-bank present? $\mathbf{Y}$ (Y or if $N$ type ctrl-n cb) 40. Where? LB (LB or RB)

41. Mid-bank distance: 87 42. Cut bank extent: 150 feet $\underline{\mathbf{U S}}$ (US, UB) to 35 feet $\underline{\mathbf{U S}}$ (US, UB, DS)

43. Bank damage: 1 (1- eroded and/or creep; 2- slip failure; 3- block failure)

44. Cut bank comments (eg. additional cut banks, protection condition, etc.):

The upstream is impacted, but due to the protection along bank and bedrock bed, the impact does not appear to be a problem. However, the left bank is evidently well eroded, many tree roots are exposed.

\section{Is channel scour present? $\mathbf{N}$ ( $Y$ or if $N$ type ctrl-n cs)}

47. Scour dimensions: Length Width Depth : 46. Mid-scour distance: -

48. Scour comments (eg. additional scour areas, local scouring process, etc.):

\section{NO CHANNEL SCOUR}

Local scour exists behind boulders.

49. Are there major confluences? $\mathbf{N}$

51. Confluence 1: Distance Confluence 2: Distance -
52. Enters on -

Enters on -
( $Y$ or if $N$ type ctrl-n $m c)$ ( $L B$ or $R B)$ (LB or $R B)$

54. Confluence comments (eg. confluence name):

NO MAJOR CONFLUENCES

A 1.5 feet in diameter culvert enters the upstream right bank 95.5 feet from upstream bridge face.

\section{Under Bridge Channel Assessment}

55. Channel restraint (BF)? LB 2

\begin{tabular}{|ccccc}
\hline \multicolumn{2}{|c}{ 56. Height (BF) } & \multicolumn{2}{c}{57 Angle (BF) } \\
LB & RB & LB & RB \\
$\mathbf{6 6 . 0}$ & & & $\mathbf{3 . 5}$ & \\
\hline
\end{tabular}
(1- natural bank; 2- abutment; 3- artificial levee)

50. How many? -

53. Type(1- perennial; 2- ephemeral)

Type (1-perennial; 2- ephemeral)

58. Bank width (BF) -

59. Channel width (Amb) -

61. Material (BF)

LB $\quad$ RB

$\underline{2} \quad \underline{7}$
62. Erosion (BF)

LB RB

7

63. Bed Material -

Bed and bank Material: 0- organics; 1- silt / clay, < 1/16mm; 2- sand, 1/16 - 2mm; 3- gravel, 2 - 64mm; 4- cobble, 64 - 256mm; 5- boulder, > 256mm; 6- bedrock; 7- manmade

Bank Erosion: 0- not evident; 1- light fluvial; 2- moderate fluvial; 3- heavy fluvial / mass wasting

64. Comments (bank material variation, minor inflows, protection extent, etc.):

532

Concrete has eroded from both abutment faces and all wingwalls. 
65. Debris and Ice Is there debris accumulation?

(Yor $N)$ 66. Where? $\underline{Y}$

(1- Upstream; 2- At bridge; 3- Both)

67. Debris Potential $\underline{3}$

( 1- Low; 2- Moderate; 3- High)

68. Capture Efficiency 2

(1-Low; 2- Moderate; 3- High)

69. Is there evidence of ice build-up? 1 (Y or $N)$

Ice Blockage Potential $\mathbf{N}$

(1-Low; 2- Moderate; 3- High)

70. Debris and Ice Comments:

1

66: Debris has accumulated on point bar upstream, along the left bank, in front of the left wingwall and on downstream channel bar.

\begin{tabular}{|l|c|c|c|c|c|c|c|c|}
\hline Abutments & $\begin{array}{c}\text { 71. Attack } \\
\angle \text { (BF) }\end{array}$ & $\begin{array}{c}\text { 72. Slope } \angle \\
\text { (Qmax) }\end{array}$ & $\begin{array}{c}\text { 73. Toe } \\
\text { loc. (BF) }\end{array}$ & $\begin{array}{c}\text { 74. Scour } \\
\text { Condition }\end{array}$ & $\begin{array}{c}\text { 75. Scour } \\
\text { depth }\end{array}$ & $\begin{array}{c}\text { 76. Exposure } \\
\text { depth }\end{array}$ & 77. Material & 78. Length \\
\hline LABUT & & - & $\mathbf{9 0}$ & $\mathbf{2}$ & $\mathbf{0}$ & - & - & $\mathbf{9 0 . 0}$ \\
\hline RABUT & $\mathbf{1}$ & $\mathbf{3 0}$ & $\mathbf{9 0}$ & & & $\mathbf{2}$ & $\mathbf{3}$ & $\mathbf{6 8 . 5}$ \\
\hline
\end{tabular}

Pushed: $L B$ or RB

Toe Location (Loc.): 0- even, 1- set back, 2- protrudes

Scour cond.: 0- not evident; 1- evident (comment); 2- footing exposed; 3-undermined footing; 4- piling exposed; 5- settled; 6- failed

Materials: 1- Concrete; 2- Stone masonry or drywall; 3- steel or metal; 4- wood

79. Abutment comments (eg. undermined penetration, unusual scour processes, debris, etc.):

1

3 Looking downstream: left low steel $\longrightarrow$

72: The left abutment is vertical, but it ld6eshotraxtend directly upward to tow stight(aleutheegt below).

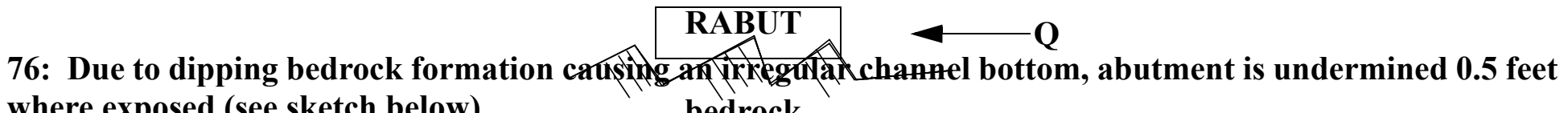
where exposed (see sketch below). bedrock

80. Wingwalls:

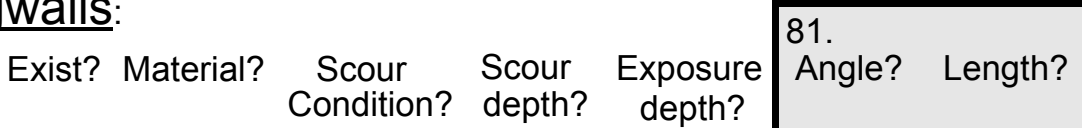

USLWW:

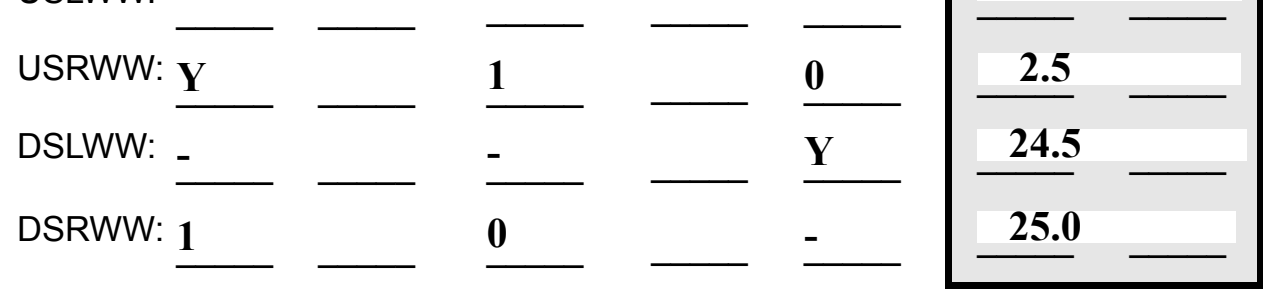

Wingwall materials: 1- Concrete; 2- Stone masonry or drywall; 3- steel or metal; 4- wood

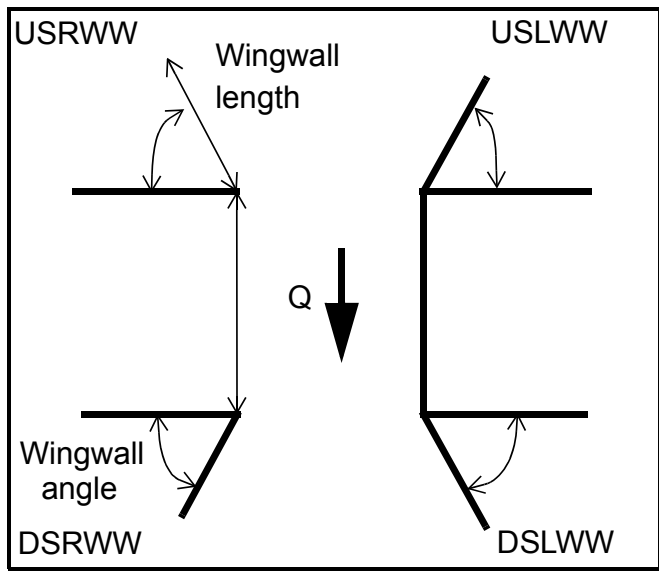

82. Bank / Bridge Protection:

\begin{tabular}{|l|l|l|l|l|l|l|l|l|}
\hline Location & USLWW & USRWW & LABUT & RABUT & LB & RB & DSLWW & DSRWW \\
\hline Type & - & $\mathbf{0}$ & $\mathbf{Y}$ & - & $\mathbf{1}$ & $\mathbf{1}$ & - & - \\
\hline Condition & $\mathbf{Y}$ & - & $\mathbf{1}$ & - & $\mathbf{1}$ & $\mathbf{1}$ & - & - \\
\hline Extent & $\mathbf{1}$ & - & $\mathbf{0}$ & $\mathbf{1}$ & $\mathbf{3}$ & $\mathbf{0}$ & $\mathbf{0}$ & - \\
\hline
\end{tabular}

Bank / Bridge protection types: 0- absent; 1- < 12 inches; 2- < 36 inches; 3- < 48 inches; 4- < 60 inches; 
83. Wingwall and protection comments (eg. undermined penetration, unusual scour processes, etc.):

-
-
-
-
-
2
2
3
3
2
3

\section{Piers:}

84. Are there piers? Up (Y or if $N$ type ctrl-n pr)

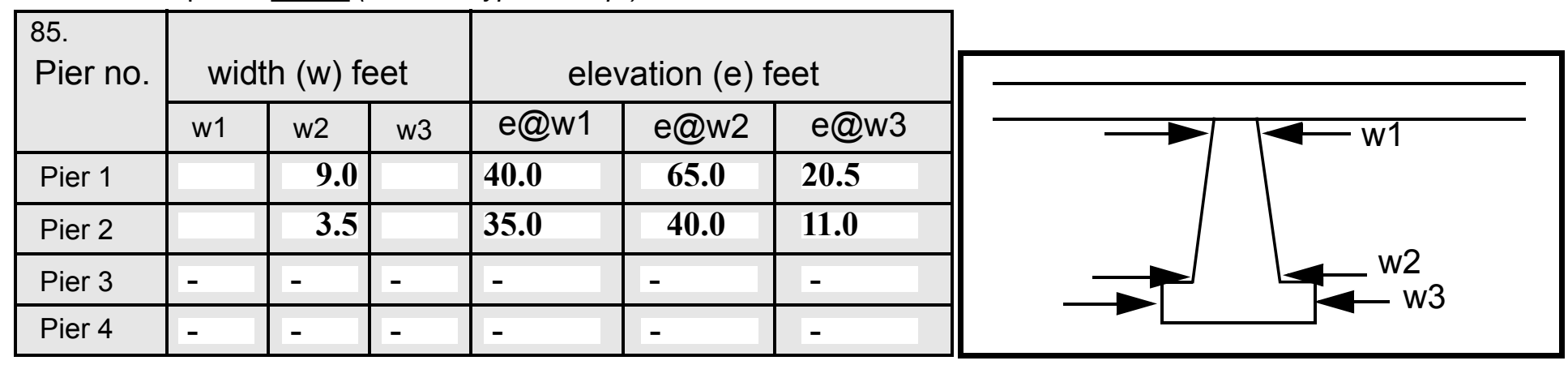

\begin{tabular}{|c|c|c|c|c|}
\hline Level 1 Pier Descr. & 1 & 2 & 3 & 4 \\
\hline 86. Location (BF) & strea & bed- & acts & adja- \\
\hline 87. Type & $\mathbf{m}$ & rock. & like & cent \\
\hline 88. Material & right & & pro- & to \\
\hline 89. Shape & wing & Bed- & tec- & the \\
\hline 90. Inclined? & wall & rock & tion. & point \\
\hline 91. Attack $\angle$ (BF) & pro- & alon & The & bar \\
\hline 92. Pushed & tec- & g & wate & unde \\
\hline 93. Length (feet) & - & - & - & - \\
\hline 94. \# of piles & tion & right & $\mathbf{r}$ & $\mathbf{r}$ \\
\hline 95. Cross-members & is & side & flows & brid \\
\hline 96. Scour Condition & boul- & of & the & ge. \\
\hline 97. Scour depth & der & chan & fast- & \\
\hline 98. Exposure depth & and & nel & est & \\
\hline
\end{tabular}

LFP, LTB, LB, MCL, MCM, MCR, RB, RTB, RFP

1- Solid pier, 2-column, 3- bent

1-Wood; 2- concrete; 3- metal; 4- stone

1- Round; 2- Square; 3- Pointed

$Y$ - yes; $N$ - no

$L B$ or $R B$

0- none; 1- laterals; 2- diagonals; 3- both

0- not evident; 1- evident (comment);

2- footing exposed; 3- piling exposed;

4- undermined footing; 5- settled; 6- failed 
99. Pier comments (eg. undermined penetration, protection and protection extent, unusual scour processes, etc.):

N
-
-
-
-

100.

\section{E. Downstream Channel Assessment}

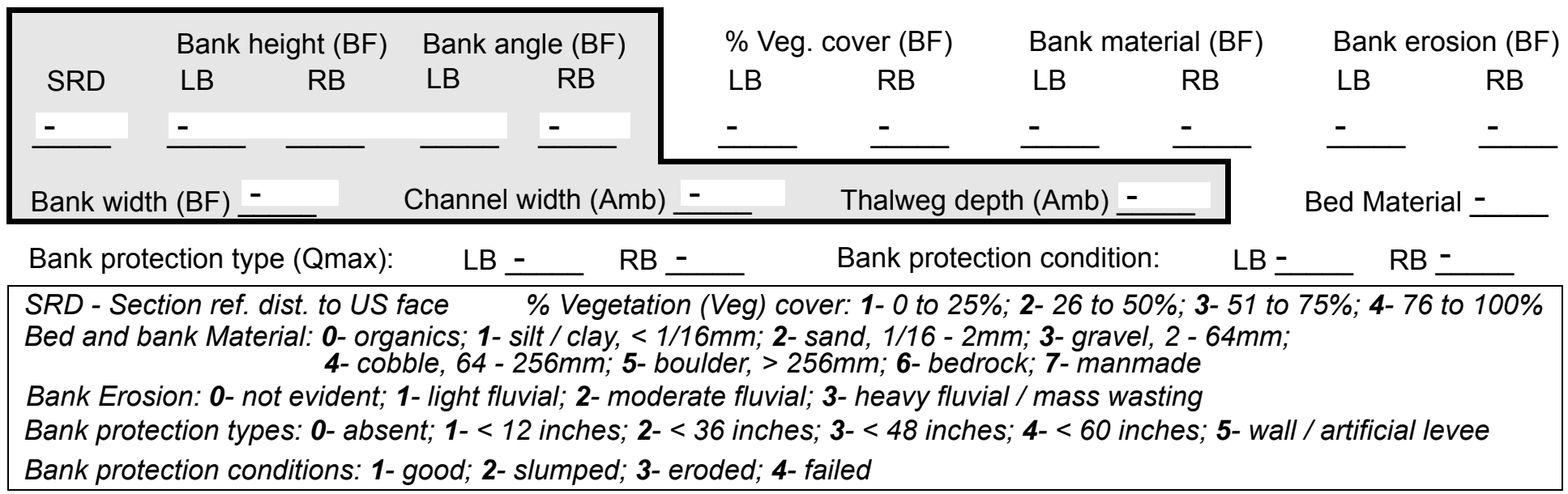

Comments (eg. bank material variation, minor inflows, protection extent, etc.):

$-$

$-$

$-$

$-$

$-$

$-$

$-$

$-$

$-$

$-$

$-$

$-$

$-$

$-$

$-$

101. Is a drop structure present? _ ( $Y$ or $N$, if $N$ type ctrl-n ds) 102. Distance: ___ feet 103. Drop: __ feet 104. Structure material: ___ (1- steel sheet pile; 2- wood pile; 3- concrete; 4- other) 105. Drop structure comments (eg. downstream scour depth):

$-$

$-$

$-$

$-$

$-$

$-$ 
106. Point/Side bar present? (Y or N. if N type ctrl-n pb)Mid-bar distance:

Mid-bar width: -

Point bar extent: feet (US, UB, DS) to feet (US, UB, DS) positioned $\%$ LB to $\% \mathrm{RB}$

Material:

Point or side bar comments (Circle Point or Side; note additional bars, material variation, status, etc.):

\section{NO PIERS}

Is a cut-bank present?

Cut bank extent: feet ( $Y$ or if $N$ type ctrl-n cb) Where? (LB or $R B$ ) feet 3 (US, UB, DS)

Bank damage: 1 (US, UB, DS) to (1- eroded and/or creep; 2- slip failure; 3- block failure)

Cut bank comments (eg. additional cut banks, protection condition, etc.):

3245

3245

1

1

Is channel scour present? $\underline{\mathbf{4 5 3}}$ (Y or if $N$ type ctrl-n cs) Mid-scour distance: $\underline{\mathbf{0}}$ Scour dimensions: Length 3 Width Depth: 2

Scour comments (eg. additional scour areas, local scouring process, etc.):

bank protection has slumped into the stream. It extends from 0 feet downstream to 25 feet downstream.

A minor inflow enters the New Haven River at 80 feet downstream on the left bank. The width of the inflow is Are there major confluences? 1 ( 1 or if $N$ type ctrl-n $m c)$ How many? foot. Confluence 1: Distance Whe Enters on $\underline{\text { re }}(L B$ or $R B)$ Type the (1- perennial; 2- ephemeral)

Confluence 2: Distance small Enters on inflo $(L B$ or $R B)$ Type $\underline{\mathbf{w}}$ (1- perennial; 2- ephemeral) Confluence comments (eg. confluence name):

enters, an $8 \mathrm{ft}$. wide silt and sand side bar exists. The side bar is 12 feet in length.

\section{F. Geomorphic Channel Assessment}

107. Stage of reach evolution
1- Constructed

2- Stable

3- Aggraded

4- Degraded

5- Laterally unstable

6- Vertically and laterally unstable 
108. Evolution comments (Channel evolution not considering bridge effects; See HEC-20, Figure 1 for geomorphic descriptors):

$\mathbf{N}$

NO DROP STRUCTURE 


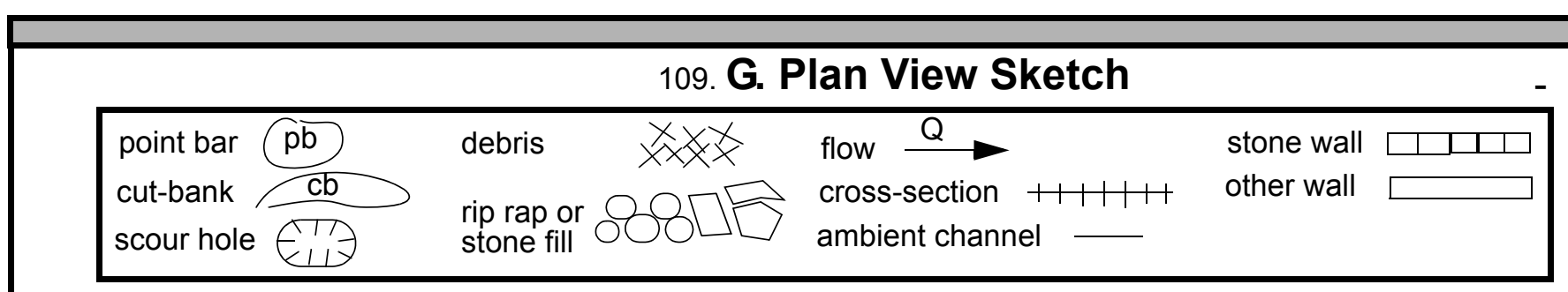


APPENDIX F:

SCOUR COMPUTATIONS 
SCOUR COMPUTATIONS

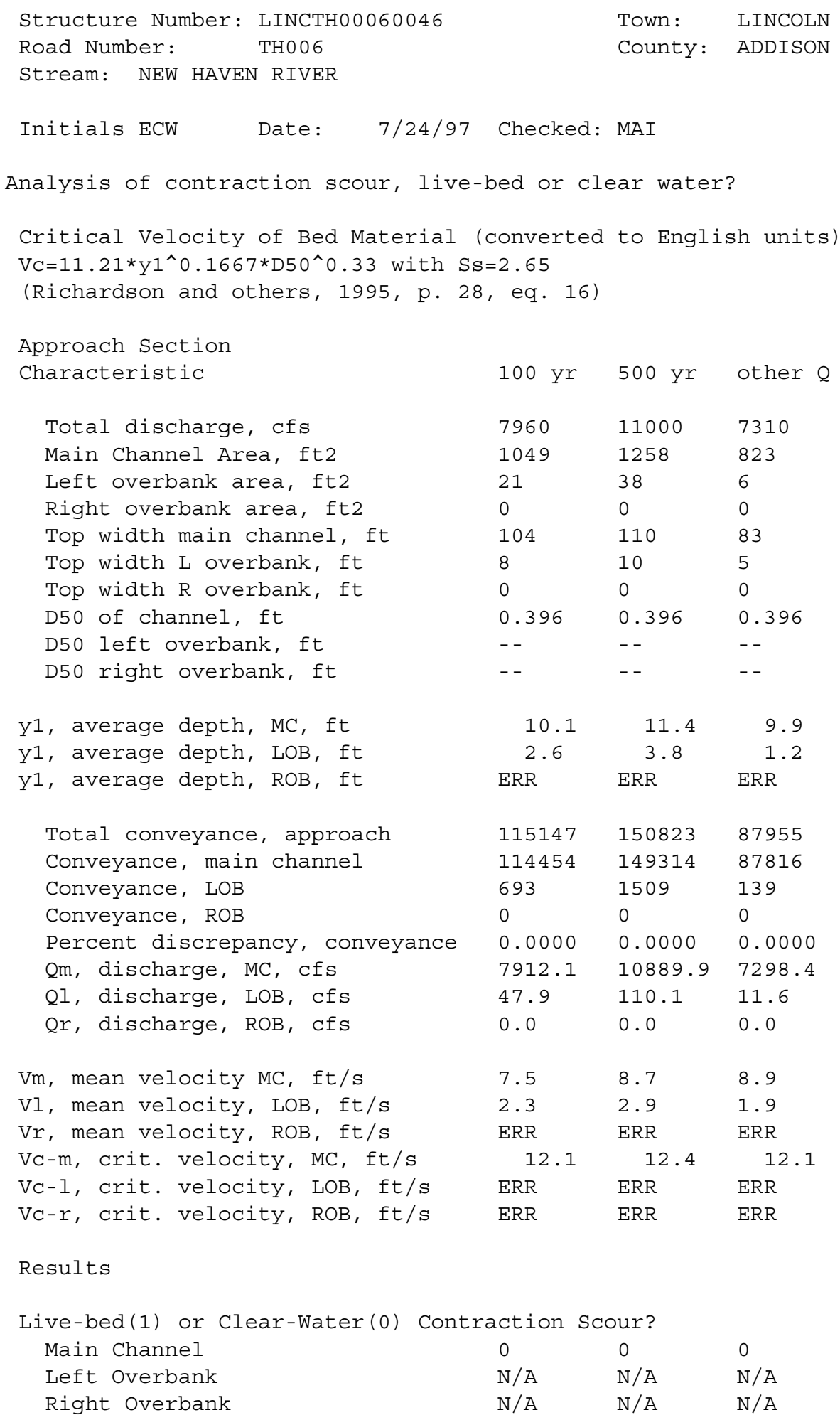


Clear water Contraction Scour in MAIN CHANNEL

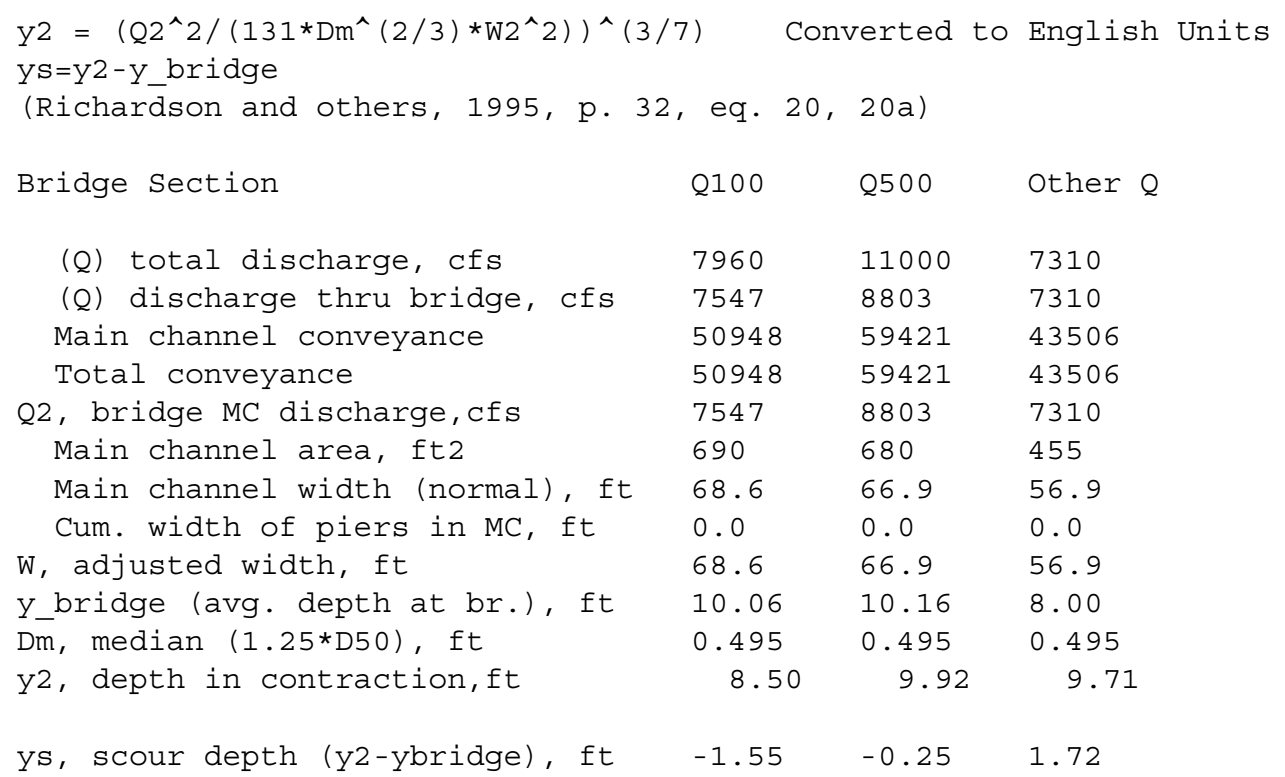

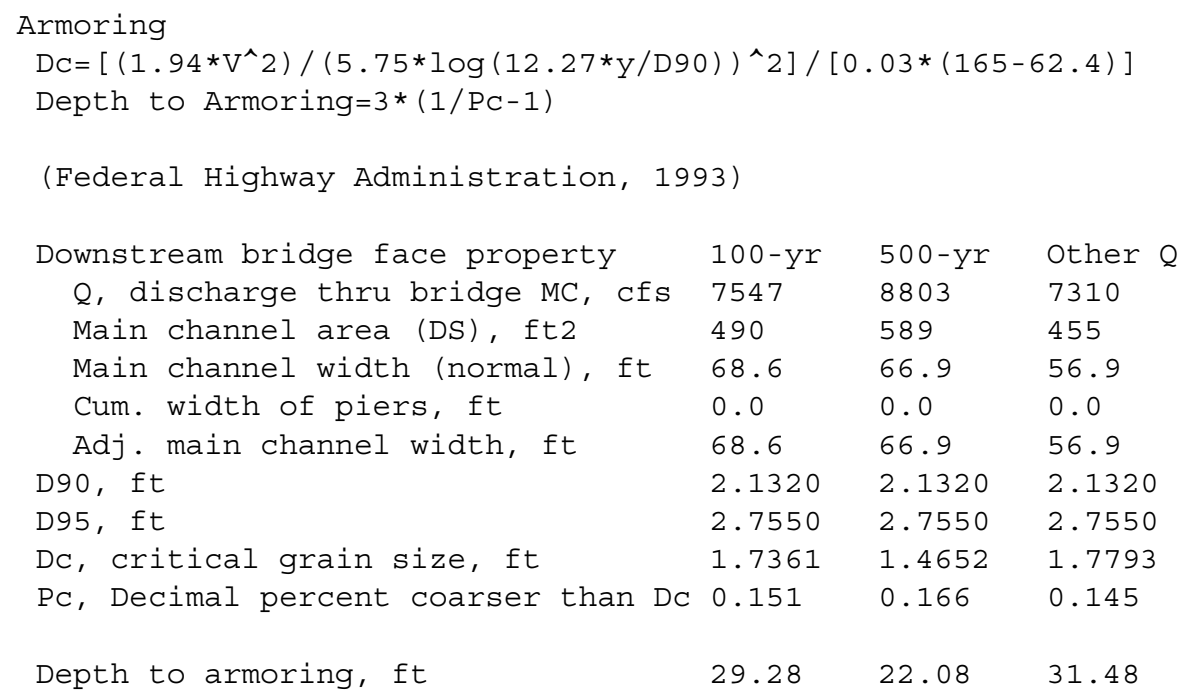




\begin{tabular}{|c|c|c|c|c|}
\hline $\begin{array}{l}\text { Chang pressure flow equation } \\
\mathrm{Cq}=1 / \mathrm{Cf} * \mathrm{CC} \quad \mathrm{Cf}=1.5 * \mathrm{Fr}^{\wedge} 0.43(<=1) \\
\text { Umbrell pressure flow equation } \\
\text { (Hb+Ys)/ya=1.1021*[(1-w/ya)*(Va/VC) } \\
\text { (Richardson and other, 1995, p. } 144\end{array}$ & $\begin{array}{l}\mathrm{Hb}+\mathrm{YS}=\mathrm{CC} \\
\mathrm{CC}=\mathrm{SQRT} \\
\wedge 0.6031 \\
-146)\end{array}$ & $\begin{array}{l}\text { * qur / Vc } \\
0.10(\mathrm{Hb} /(\mathrm{y}\end{array}$ & $(y a-w)-0.56)]+0.79$ & $(<=1)$ \\
\hline & Q100 & Q500 & OtherQ & \\
\hline Q, total, cfs & 7960 & 11000 & 7310 & \\
\hline Q, thru bridge $\mathrm{MC}$, cfs & 7547 & 8803 & 7310 & \\
\hline Vc, critical velocity, ft/s & 12.10 & 12.36 & 12.07 & \\
\hline Va, velocity MC approach, ft/s & 7.54 & 8.66 & 8.87 & \\
\hline Main channel width (normal), ft & 68.6 & 66.9 & 56.9 & \\
\hline Cum. width of piers in MC, ft & 0.0 & 0.0 & 0.0 & \\
\hline W, adjusted width, ft & 68.6 & 66.9 & 56.9 & \\
\hline qbr, unit discharge, ft2/s & 110.0 & 131.6 & 128.5 & \\
\hline Area of full opening, ft2 & 690.0 & 680.0 & 455.0 & \\
\hline $\mathrm{Hb}$, depth of full opening, ft & 10.06 & 10.16 & 8.00 & \\
\hline Fr, Froude number, bridge $\mathrm{MC}$ & 0.61 & 0.73 & 0 & \\
\hline Cf, Fr correction factor $(<=1.0)$ & 1.00 & 1.00 & 0.00 & \\
\hline **Area at downstream face, ft2 & 490 & 589 & $\mathrm{~N} / \mathrm{A}$ & \\
\hline$* * \mathrm{Hb}$, depth at downstream face, ft & 7.14 & 8.80 & $\mathrm{~N} / \mathrm{A}$ & \\
\hline$\star *$ Fr, Froude number at DS face & 1.02 & 0.89 & ERR & \\
\hline$* * C f$, for downstream face $(<=1.0)$ & 1.00 & 1.00 & $\mathrm{~N} / \mathrm{A}$ & \\
\hline Elevation of Low steel, ft & 496 & 496 & 0 & \\
\hline Elevation of Bed, ft & 485.94 & 485.84 & -8.00 & \\
\hline Elevation of Approach, ft & 499.3 & 501.21 & 0 & \\
\hline Friction loss, approach, ft & 0.59 & 0.64 & 0 & \\
\hline Elevation of WS immediately US, ft & 498.71 & 500.57 & 0.00 & \\
\hline ya, depth immediately US, ft & 12.77 & 14.73 & 8.00 & \\
\hline Mean elevation of deck, ft & 499.1 & 499.1 & 0 & \\
\hline w, depth of overflow, ft $(>=0)$ & 0.00 & 1.47 & 0.00 & \\
\hline Cc, vert contrac correction $(<=1.0)$ & 0.94 & 0.93 & 1.00 & \\
\hline$* * C c$, for downstream face $(<=1.0)$ & 0.79 & 0.891855 & $\mathrm{ERR}$ & \\
\hline Ys, scour w/Chang equation, ft & -0.40 & 1.24 & $\mathrm{~N} / \mathrm{A}$ & \\
\hline Ys, scour w/Umbrell equation, ft & 0.52 & 2.13 & $\mathrm{~N} / \mathrm{A}$ & \\
\hline
\end{tabular}




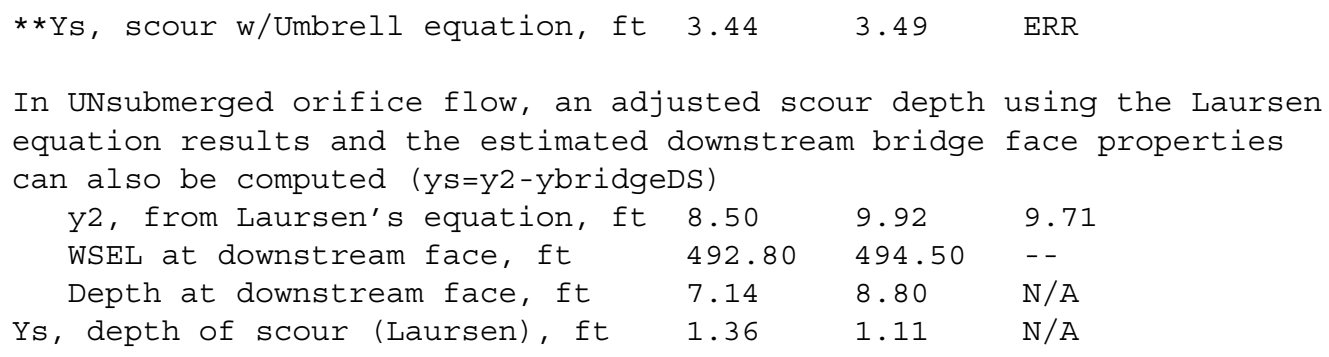

Abutment scour

Froehlich's Abutment Scour

$\mathrm{Ys} / \mathrm{Y} 1=2.27 * \mathrm{~K} 1 * \mathrm{~K} 2 *\left(\mathrm{a}^{\prime} / \mathrm{Y} 1\right)^{\wedge} 0.43 * \mathrm{Fr} 1^{\wedge} 0.61+1$

(Richardson and others, 1995, p. 48, eq. 28)

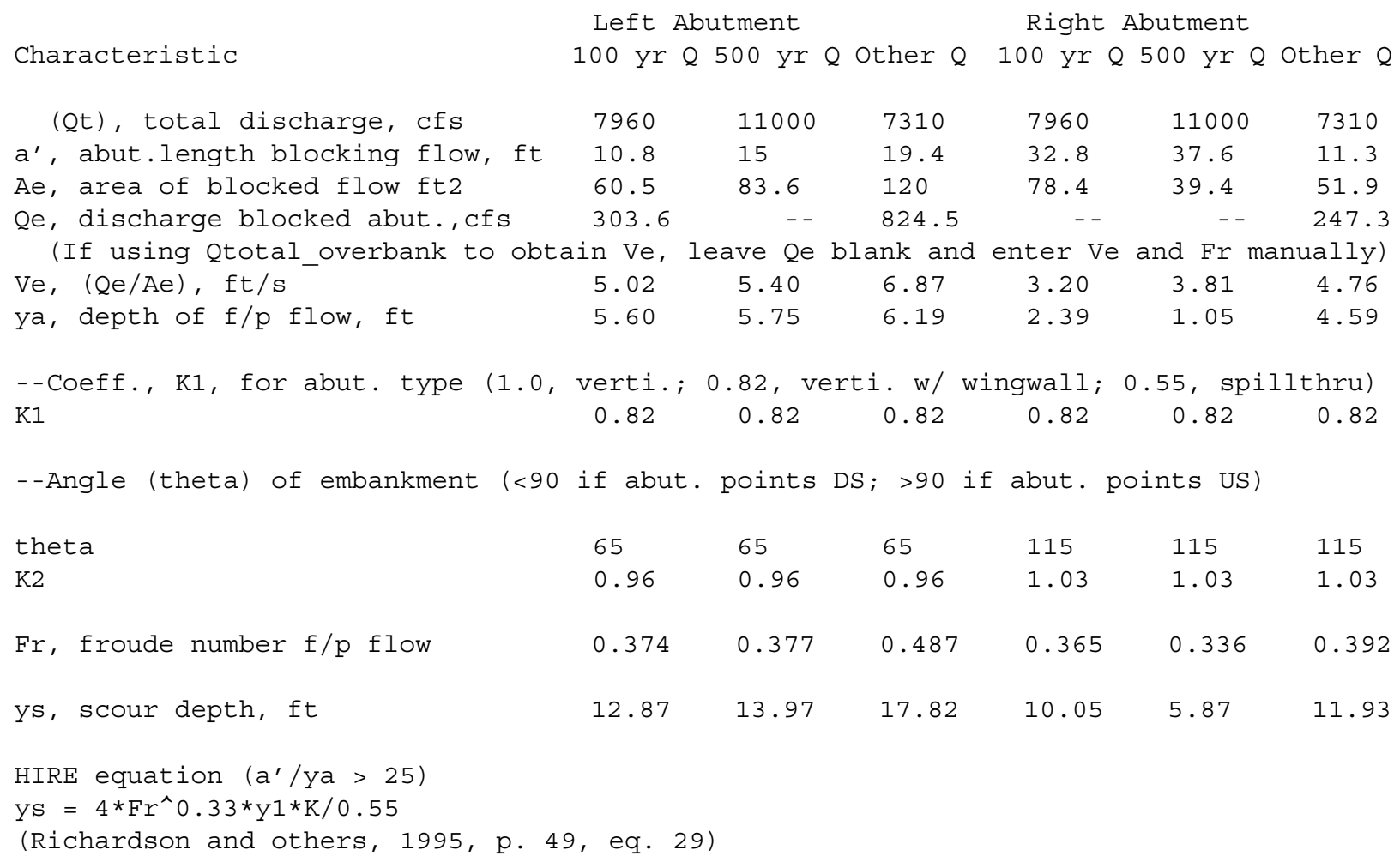




\begin{tabular}{|c|c|c|c|c|c|c|}
\hline $\mathrm{a}^{\prime}$ (abut length blocked, ft) & 10.8 & 15 & 19.4 & 32.8 & 37.6 & 11.3 \\
\hline y1 (depth f/p flow, ft) & 5.60 & 5.75 & 6.19 & 2.39 & 1.05 & 4.59 \\
\hline$a^{\prime} / y^{\prime}$ & 1.93 & 2.69 & 3.14 & 13.72 & 35.88 & 2.46 \\
\hline Skew correction (p. 49, fig. 16) & 0.92 & 0.92 & 0.92 & 1.06 & 1.06 & 1.06 \\
\hline Froude no. f/p flow & 0.37 & 0.38 & 0.49 & 0.36 & 0.34 & 0.39 \\
\hline Ys w/ corr. factor $\mathrm{Kl} / 0.55$ : & & & & & & \\
\hline vertical & ERR & $\mathrm{ERR}$ & ERR & ERR & 5.62 & ERR \\
\hline vertical w/ ww's & ERR & ERR & ERR & ERR & 4.60 & ERR \\
\hline spill-through & ERR & ERR & ERR & ERR & 3.09 & ERR \\
\hline Abutment riprap sizing & & & & & & \\
\hline Isbash Relationship & & & & & & \\
\hline $\mathrm{D} 50=\mathrm{Y} * \mathrm{~K} * \mathrm{Fr} r^{\wedge} 2 /(\mathrm{Ss}-1)$ and $\mathrm{D} 50=\mathrm{Y} * \mathrm{~K} *($ & $2)^{\wedge} 0$ & $(\mathrm{Ss}-1)$ & & & & \\
\hline (Richardson and others, 1995, p11 & eq. $\varepsilon$ & & & & & \\
\hline Characteristic & Q100 & Q500 & Other $Q$ & Q100 & Q500 & Other $Q$ \\
\hline Fr, Froude Number & 1.02 & 0.89 & 1 & 1.02 & 0.89 & 1 \\
\hline$y$, depth of flow in bridge, ft & 7.14 & 8.80 & 8.00 & 7.14 & 8.80 & 8.00 \\
\hline Median Stone Diameter for riprap & left & outment & & right & abutment, & ft \\
\hline Fr $<=0.8$ (vertical abut.) & $E R R$ & $E R R$ & ERR & $E R R$ & $E R R$ & ERR \\
\hline Fr>0.8 (vertical abut.) & 3.00 & 3.56 & 3.35 & 3.00 & 3.56 & 3.35 \\
\hline
\end{tabular}

